\title{
STAT5 programs a distinct subset of GM-CSF-producing $T$ helper cells that is essential for autoimmune neuroinflammation
}

Wanqiang Sheng ${ }^{1,2}$, Fan Yang ${ }^{1}$, Yi Zhou ${ }^{3}$, Henry Yang ${ }^{1}$, Pey Yng Low ${ }^{4}$, David Michael Kemeny ${ }^{4}$, Patrick Tan ${ }^{1,5}$, Akira $\mathrm{Moh}^{7}$, Mark H Kaplan ${ }^{7,8}$, Yongliang Zhang ${ }^{4}$, Xin-Yuan Fu ${ }^{1,3,6,8}$

${ }^{I}$ Cancer Science Institute of Singapore, YLL School of Medicine, National University of Singapore, Singapore; ${ }^{2}$ Department of Biological Sciences, Faculty of Science, National University of Singapore, Singapore; ${ }^{3}$ Department of Biochemistry, YLL School of Medicine, National University of Singapore, Singapore; ${ }^{4}$ Immunology Programme and Department of Microbiology, YLL School of Medicine, National University of Singapore, Singapore; ${ }^{5}$ Cancer and Stem Cell Biology, Duke-NUS Graduate Medical School, Singapore; ${ }^{6}$ Neurobiology Programme, Life Sciences Institute, National University of Singapore, Singapore; ${ }^{7}$ Departments of Pediatrics and Herman $B$ Wells Center for Pediatric Research, ${ }^{8}$ Department of Microbiology and Immunology, Indiana University School of Medicine, Indianapolis, IN 46202, USA

$T$ helper $\left(T_{H}\right)$-cell subsets, such as $T_{H} 1$ and $T_{H} 17$, mediate inflammation in both peripheral tissues and central nervous system. Here we show that STAT5 is required for $\mathrm{T}$ helper-cell pathogenicity in autoimmune neuroinflammation but not in experimental colitis. Although STAT5 promotes regulatory $\mathrm{T}$ cell generation and immune suppression, loss of STAT5 in $\mathrm{CD}^{+} \mathrm{T}$ cells resulted in diminished development of experimental autoimmune encephalomyelitis (EAE), a mouse model of multiple sclerosis. Our results showed that loss of encephalitogenic activity of STAT5-deficient autoreactive $\mathrm{CD}^{+} \mathrm{T}$ cells was independent of IFN- $\gamma$ or interleukin 17 (IL-17) production, but was due to the impaired expression of granulocyte-macrophage colony-stimulating factor (GM-CSF), a crucial mediator of T-cell pathogenicity. We further showed that IL-7-activated STAT5 promotes the generation of GM-CSF-producing CD4 ${ }^{+}$T cells, which were preferentially able to induce more severe EAE than $T_{H} 17$ or $T_{H} 1$ cells. Consistent with GM-CSF-producing cells being a distinct subset of $T_{H}$ cells, the differentiation program of these cells was distinct from that of $T_{H} 17$ or $T_{H} 1$ cells. We further found that IL-3 was secreted in a similar pattern as GM-CSF in this subset of $T_{H}$ cells. In conclusion, the IL-7-STAT5 axis promotes the generation of GM-CSF/IL-3-producing $T_{H}$ cells. These cells display a distinct transcriptional profile and may represent a novel subset of $T$ helper cells which we designate as $T_{H^{-}}-G M$.

Keywords: T helper cell; experimental autoimmune encephalomyelitis; GM-CSF; IL-7; STAT5

Cell Research (2014) 24:1387-1402. doi: 10.1038/cr.2014.154; published online 21 November 2014

\section{Introduction}

In response to antigenic assault, naïve $\mathrm{CD} 4^{+} \mathrm{T}$ cells differentiate into various subsets of effector $\mathrm{T}$ helper $\left(\mathrm{T}_{\mathrm{H}}\right)$ cells with differential cytokine production profiles and distinct functions [1-3]. Inflammatory cytokines direct

Correspondence: Yongliang Zhang ${ }^{\mathrm{a}}$, Xin-Yuan $\mathrm{Fu}^{\mathrm{b}}$

${ }^{a}$ E-mail: miczy@nus.edu.sg

bE-mail: xin-yuan_fu@nuhs.edu.sg

Received 22 September 2014; revised 29 September 2014; accepted 9

October 2014; published online 21 November 2014 the differentiation of antigen-specific $\mathrm{CD} 4{ }^{+} \mathrm{T}$ cells by inducing the expression of subset-specific transcription factors [1]. For instance, interleukin 12 (IL-12) activates STAT4 and induces T-bet expression, which promotes $\mathrm{T}_{\mathrm{H}} 1$ differentiation and IFN- $\gamma$ production [4-6]. IL-6 signaling through STAT3, in concert with TGF- $\beta$, induces ROR $\gamma t$ expression and initiates the differentiation of $\mathrm{T}_{\mathrm{H}} 17$ cells [7-9], which is further enhanced by TNF- $\alpha$, IL-23, and IL-1 $\beta[10]$.

By coordinating both innate and adaptive effector cell activities, $\mathrm{CD}^{+} \mathrm{T}$ cells including $\mathrm{T}_{\mathrm{H}} 1, \mathrm{~T}_{\mathrm{H}} 2$, and $\mathrm{T}_{\mathrm{H}} 17$ play critical roles in host defense against infectious agents and in the pathogenesis of various autoimmune 
diseases [11]. For example, both $T_{H} 1$ and $T_{H} 17$ cells are considered major mediators of autoimmune neuroinflammation in multiple sclerosis (MS) and experimental autoimmune encephalomyelitis (EAE) [2, 12, 13]. However, mice deficient in IFN- $\gamma$ or IL-12 (p35) show exacerbated EAE development, whereas mice deficient in IL-23 (p19) are resistant to EAE [14-17]. Loss of ROR $\gamma t$ or STAT3, the master regulators of $\mathrm{T}_{\mathrm{H}} 17$ cells, attenuates the development of EAE $[8,18]$. These studies suggest that $T_{H} 17$, rather than $\mathrm{T}_{\mathrm{H}} 1$ cells, are the main encephalitogenic population in autoimmune neuroinflammation. However, the role of $\mathrm{T}_{\mathrm{H}} 17$ in MS and EAE is still in debate since none of the $\mathrm{T}_{\mathrm{H}} 17$-hallmark cytokines, including IL-17, IL$17 \mathrm{~F}$, and IL-22, is mandatory for EAE development [12, $19,20]$. More recently, granulocyte-macrophage colony-stimulating factor (GM-CSF) secreted by autoreactive $\mathrm{T}$ cells was identified as a potential encephalitogenic factor to sustain neuroinflammation [21-23].

STAT5 transmits IL-2 signal and is crucial for regulatory $\mathrm{T}\left(\mathrm{T}_{\text {reg }}\right)$ cell development [24], but also negatively regulates $T_{H} 17$ differentiation $[25,26]$. However, its function in $\mathrm{T}$ cell-mediated autoimmune diseases has not been well documented. In this study, surprisingly, we found that STAT5 was indispensible for the encephalitogenicity of autoreactive $\mathrm{CD} 4^{+} \mathrm{T}$ cells in EAE. Further investigation showed that IL-7-STAT5 signaling axis induced optimal GM-CSF production in pathogenic $\mathrm{CD} 4^{+} \mathrm{T}$ cells, which was important for inducing effective neuroinflammation. In vitro studies showed that GM-CSF-producing $\mathrm{CD} 4^{+} \mathrm{T}$ cells regulated by IL-7STAT5 signaling axis may represent a new $T_{H}$ subset with a distinct differentiation program and cytokine production profile.

\section{Results}

Mice with Stat5 deletion in T cells are resistant to EAE

To examine the role of STAT5 in T cell-mediated pathogenesis, we induced EAE in Cd4-Cre; Stat $5^{\mathrm{f} / \mathrm{f}}$ $\left(S t a t 5^{-/}\right)$mice [27], where Stat $5 a / b$ loci were specifically deleted in $\mathrm{CD}^{+}$and $\mathrm{CD}^{+} \mathrm{T}$ cells, and Stat $^{\mathrm{ff/}}\left(\mathrm{Stat}^{+/+}\right)$ mice. We found diminished incidence and severity of EAE disease in Stat $^{-/-}$mice compared with Stat5 $5^{+/+}$ mice (Figure 1A and Supplementary information, Figure S1A and S1B), which was opposite to our expectation based on an inhibitory role of STAT5 in $\mathrm{T}_{\mathrm{H}} 17$ generation. Consistent with EAE resistance, we found a remarkable reduction of immune cell infiltration in the CNS of Stat $5^{-}$ mice (Figure 1B and Supplementary information, Figure S1C-S1F). However, the frequencies of $\mathrm{IL}-17^{+}$and $\mathrm{IFN}-\gamma^{+}$cells among $\mathrm{CD} 4^{+} \mathrm{T}$ cells in the central nervous system (CNS) were comparable between Stat $^{+/+}$and
Stat $5^{-/}$mice (Figure 1C), suggesting that the resistance to EAE in Stat $^{-/-}$mice is independent of $\mathrm{T}_{\mathrm{H}} 1$ and $\mathrm{T}_{\mathrm{H}} 17$ cells. Furthermore, we detected decreased $\mathrm{CD} 4{ }^{+} \mathrm{CD} 25^{+}$ population and reduced Foxp3 expression in Stat $5^{-/}$ mice (Figure 1D and Supplementary information, Figure S2A), indicating the resistance to EAE is unlikely due to altered $\mathrm{T}_{\text {reg }}$ cell development.

Intrinsic defect in encephalitogenicity of STAT5-deficient CD4 ${ }^{+}$T cells

To examine whether T cell-specific deletion of Stat 5 resulted in peripheral lymphopenia, we analyzed $\mathrm{T}$ cell populations in spleens of $\mathrm{MOG}_{35-55} / \mathrm{CFA}$-immunized mice. Consistent with a previous report [28], we detected reduced $\mathrm{CD}^{+} \mathrm{T}$ cell number but similar number of $\mathrm{CD}^{+} \mathrm{T}$ cells in Stat $^{-/-}$mice compared with Stat $5^{+/+}$ mice (Supplementary information, Figure S2B and S2C). Furthermore, we detected increased frequencies of both IL- $17^{+}$and IFN- $\gamma^{+} \mathrm{CD} 4^{+}$T cells in the spleens of Stat $5^{-/-}$ mice (Supplementary information, Figure S2D). To validate the function of STAT5 in $\mathrm{T}_{\mathrm{H}} 1$ and $\mathrm{T}_{\mathrm{H}} 17$ generation, we performed in vitro T-cell differentiation. As reported $[25,26]$, STAT5 mediated the suppressive effect of IL-2 on $\mathrm{T}_{\mathrm{H}} 17$ differentiation (Supplementary information, Figure S3A and S3B). STAT5 deficiency led to slightly decreased $\mathrm{T}_{\mathrm{H}} 1$-cell generation (Supplementary information, Figure S3C). Therefore, the resistance to EAE in Stat $5^{-/-}$mice is unlikely due to impaired $\mathrm{T}_{\mathrm{H}} 1-$ and $\mathrm{T}_{\mathrm{H}} 17-$ cell generation in vivo.

To address whether the resistance to EAE in Stat5 $5^{-/-}$ mice is caused by STAT5 deficiency in $\mathrm{CD} 4^{+} \mathrm{T}$ cells, we reconstituted $\mathrm{Rag}^{-/-}$mice with Stat $^{+/+}$or Stat $5^{-/}$ $\mathrm{CD}^{+} \mathrm{T}$ cells followed by EAE induction. We found that $\mathrm{Rag}^{2^{-/}}$mice receiving Stat5 ${ }^{-/-} \mathrm{CD} 4^{+} \mathrm{T}$ cells were resistant to the disease compared with mice receiving Stat $5^{+/+} \mathrm{CD}^{+} \mathrm{T}$ cells (Supplementary information, Figure S4A and S4B), demonstrating that Stat $^{-/-} \mathrm{CD}^{+} \mathrm{T}$ cells were impaired in mediating EAE development. The expression of chemokine receptors such as CCR6 and CXCR3, which are critical for $\mathrm{T}_{\mathrm{H}} 17$ or $\mathrm{T}_{\mathrm{H}} 1$ cell entry into the CNS $[29,30]$, was not impaired in Stat $^{-/-} \mathrm{CD}^{+} \mathrm{T}$ cells (Supplementary information, Figure S5A), indicating that $\mathrm{CD}^{+} \mathrm{T}$ cells with STAT5 deficiency are likely capable of infiltrating the CNS. Consistent with this, we observed comparable numbers of $\mathrm{CD}^{+} \mathrm{T}$ cells in the CNS of Stat $^{+/+}$and Stat $^{-/-}$mice before disease onset (on days 7 and 9) (Supplementary information, Figure S5B). However, during the later phase, significantly more $\mathrm{CD}^{+} \mathrm{T}$ cells accumulated in the CNS of Stat $5^{+/+}$ mice compared with Stat $^{-/-}$mice (Supplementary information, Figure S5C). These results indicate that Stat5 $5^{-1}$ $\mathrm{CD}^{+} \mathrm{T}$ cells can infiltrate the CNS but fail to induce 
A

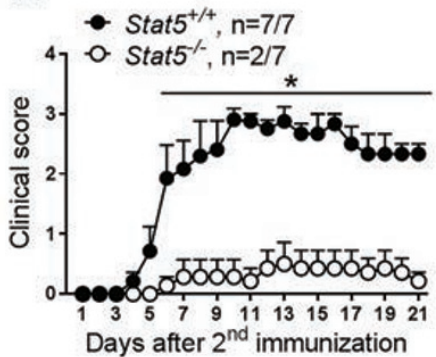

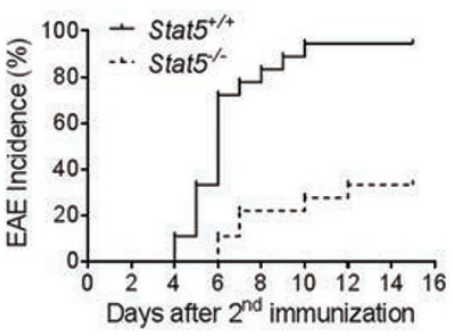

B

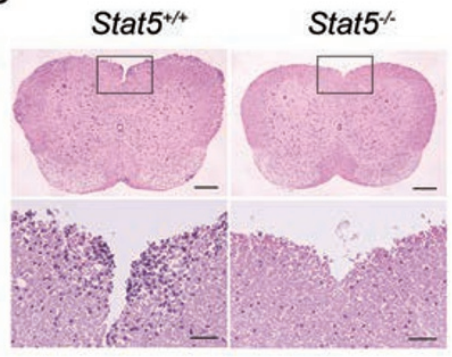

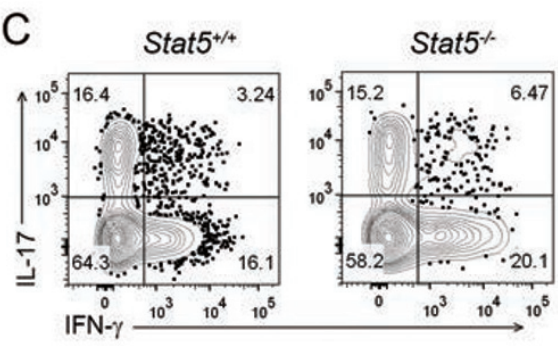

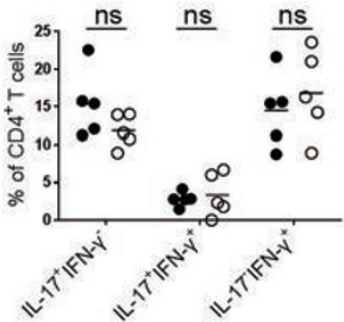

- $S t a t 5^{+/+}$

- Stat5
D

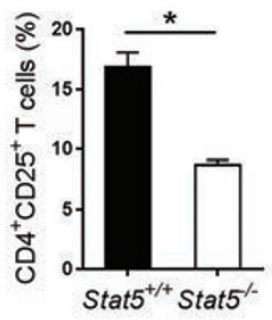

E

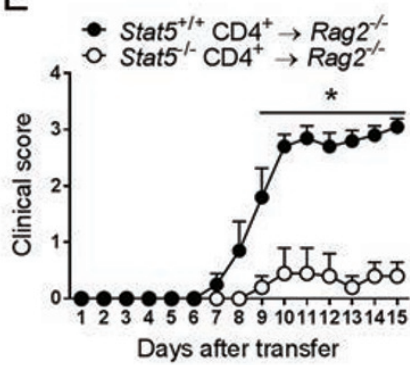

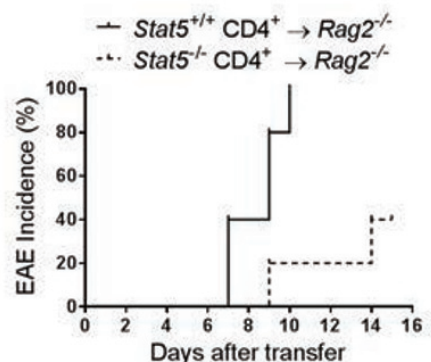

$\mathrm{F}$

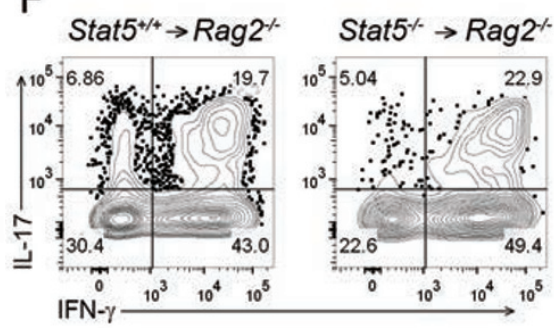

Figure 1 Stat5-conditional knockout mice are resistant to EAE. (A) Clinical EAE scores (left) and incidence (right, $n=$ eighteen of three experiments pooled) of $S t a t 5^{+/+}$and $S t a t 5^{-/-}$mice immunized twice with $\mathrm{MOG}_{35-55} / \mathrm{CFA}$. (B) Histology of spinal cord sections obtained from EAE mice on day 9 after $2^{\text {nd }}$ immunization. Scale bars, $200 \mu \mathrm{m}$ (top), $50 \mu \mathrm{m}$ (bottom). (C) Flow cytometric analysis of IL-17 and IFN- $\gamma$ expression by CNS-infiltrating $\mathrm{CD}^{+} \mathrm{T}$ cells at peak of disease. (D) Percentage of $\mathrm{CD}^{+} \mathrm{CD} 25^{+} \mathrm{T}$ cells in the CNS at peak of disease $(n=3)$. (E, F) Clinical EAE scores (E, left) and incidence (E, right) of Rag2 ${ }^{-/}$mice ( $n=5$ per group) after adoptive transfer of $2 \times 10^{6} \mathrm{MOG}_{35-55}$-reactive Stat $5^{+/}$or Stat $5^{-/-} \mathrm{CD} 4^{+} \mathrm{T}$ cells, respectively. IL-17 and IFN- $\gamma$ expression by CNS-infiltrating $\mathrm{CD}^{+} \mathrm{T}$ cells was measured by intracellular cytokine staining at the peak of disease (F). Data represent at least two independent experiments. ${ }^{*} P<0.05$; ns, not significant.

effective inflammatory responses. To further exclude the possibility that EAE resistance is due to reduction in Stat $^{-/-} \mathrm{CD}^{+} \mathrm{T}$ cell number in the CNS, we transferred more Stat $5^{-/} \mathrm{CD}^{+} \mathrm{T}$ cells than Stat $5^{+/+}$cells into Rag2 $2^{-/-}$ mice followed by $\mathrm{MOG}_{35-55} / \mathrm{CFA}$ immunization, so that comparable numbers of autoreactive $\mathrm{CD}^{+} \mathrm{T}$ cells were present in the CNS after disease onset. We still observed reduced disease severity in mice receiving Stat $5^{-/} \mathrm{CD} 4^{+}$ $\mathrm{T}$ cells (Supplementary information, Figure S6A and S6B). Together, these results suggest that the resistance to EAE disease caused by STAT5 deficiency in $\mathrm{CD} 4^{+} \mathrm{T}$ cells is unlikely due to impaired $\mathrm{CD}^{+} \mathrm{T}$ cell infiltration or survival in the CNS.

To confirm that EAE resistance caused by STAT5 deficiency is due to intrinsic impairment of autoreactive $\mathrm{CD}^{+} \mathrm{T}$ cells, we isolated $\mathrm{CD}^{+} \mathrm{T}$ cells from $\mathrm{MOG}_{35-55} /$ CFA-immunized mice and transferred ex vivo-expanded $\mathrm{MOG}_{35-55^{-}}$-reactive Stat $^{+/+}$and Stat $5^{-/-} \mathrm{CD} 4^{+} \mathrm{T}$ cells into $\operatorname{Rag} 2^{--}$mice separately without additional immunization. Mice receiving Stat $^{+/+}$cells developed EAE 1 week after the transfer (Figure 1E). In contrast, mice receiving Stat $5^{-/-} \mathrm{CD}^{+} \mathrm{T}$ cells had significantly reduced disease 
severity and incidence (Figure 1E). Of note, the frequencies of IL- $17^{+}$and/or IFN- $\gamma^{+}$cells among $\mathrm{CD} 4^{+} \mathrm{T}$ cells in the CNS were comparable between the two groups (Figure $1 \mathrm{~F}) . \mathrm{CD}^{+}$and $\mathrm{CD} 8^{+} \mathrm{T}$ cell co-transfer experiments demonstrate that the resistance to EAE observed in Stat $5^{-/-}$mice was not due to $\mathrm{CD} 8^{+} \mathrm{T}$ cells (Supplementary information, Figure S7A and S7B). Therefore, Stat $5^{-1}$ $\mathrm{CD}^{+} \mathrm{T}$ cells are intrinsically defective in encephalitogenicity, independent of $\mathrm{T}_{\mathrm{H}} 1$ - and $\mathrm{T}_{\mathrm{H}} 17$-cell generation.

\section{STAT5 deficiency in $\mathrm{CD}^{+} \mathrm{T}$ cells causes impaired ex- pression of GM-CSF}

Communication between CNS-infiltrating $\mathrm{CD} 4^{+} \mathrm{T}$ cells and myeloid cells is critical for inducing effective neuroinflammation $[21,22]$. GM-CSF production by encephalitogenic $\mathrm{CD}^{+} \mathrm{T}$ cells, not other types of cells, is essential for microglial cell activation, peripheral myeloid cell recruitment and EAE development [23]. To test whether GM-CSF production was impaired upon Stat 5 depletion, we examined GM-CSF expression in $\mathrm{MOG}_{35-55}$-specific $\mathrm{CD}^{+} \mathrm{T}$ cells. We found that GM-CSF production was robustly increased in a dose-dependent manner in Stat $^{+/+}$, but not in Stat $5^{-/-}$cells, upon antigen re-stimulation (Figure 2A). Antigen-specific $\mathrm{CD}^{+} \mathrm{T}$ cells with STAT5 deficiency contained significantly reduced percentages of GM-CSF-producers in both IL- $17^{+}$and IL-17 populations (Figure $2 \mathrm{~B}$ ). Of note, the frequency of IL-17-producing $\mathrm{CD} 4^{+} \mathrm{T}$ cells was increased with STAT5 deficiency (Figure 2B). Together, these results suggest that STAT5 is required for GM-CSF expression by antigen-specific $\mathrm{CD} 4^{+} \mathrm{T}$ cells.

Next, we examined GM-CSF expression in the CNS during EAE development. Although IL-17 and IFN- $\gamma$ expression by CNS-infiltrating Stat $5^{-/-} \mathrm{CD}^{+} \mathrm{T}$ cells was not impaired (Figure 1C), we detected a significantly diminished frequency of $\mathrm{CD}^{+} \mathrm{GM}^{-\mathrm{CSF}^{+}}$cells in the CNS of $S t a t 5^{-/}$mice compared with control mice (Figure 2C).

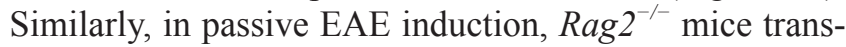
ferred with STAT5-deficient $\mathrm{MOG}_{35-55}$-reactive CD4 $\mathrm{T}$ cells also showed a reduced frequency of $\mathrm{CD}^{+} \mathrm{GM}-$ $\mathrm{CSF}^{+} \mathrm{T}$ cells in the CNS compared with mice transferred with wild-type (WT) cells (Figure 2D). Time-course analysis of cytokine induction in the whole CNS tissues showed that GM-CSF mRNA expression in Stat $^{+/+}$mice was markedly increased as early as day 8 after $\mathrm{MOG}_{35}$ ${ }_{55}$ /CFA immunization, whereas GM-CSF induction in Stat $^{-/-}$mice was significantly diminished (Figure 2E). Meanwhile, no significant difference in IL-17 or IFN- $\gamma$ expression was detected between Stat $^{-/-}$and Stat $5^{+/+}$ mice on day 8 post-immunization (Figure 2E). The reduced IL-17 expression in the CNS of Stat $5^{-/}$mice at a later stage (day 14, Figure 2E) could be explained by the inability of Stat $5^{-/-} \mathrm{CD} 4^{+} \mathrm{T}$ cells to induce effective neuroinflammation with a result of decreased inflammatory cell infiltration (Supplementary information, Figures $\mathrm{S} 1$ and S5C). We also observed the expression level of IL-23, an important inflammatory cytokine mainly produced by dendritic cells (DCs) [16], was reduced in the CNS of Stat $^{-/-}$mice compared with $S t a t 5^{+/+}$mice, paralleling decreased IL-17 expression level (Figure 2E). Interestingly, the expression level of IL-23 in the CNS of Stat $^{+/+}$mice was only significantly increased on day 14 after disease induction (Figure 2E), suggesting that IL23 might not be required for GM-CSF expression and EAE induction at the early stage. Together, these results demonstrate that STAT5 deficiency in $\mathrm{CD}^{+} \mathrm{T}$ cells results in impaired GM-CSF expression, which is associated with EAE resistance.

\section{IL-7-STAT5 signaling induces GM-CSF expression in au- toreactive $C D 4^{+}$T cells}

We next investigated the possible cytokine(s) that signal through STAT5 to regulate GM-CSF expression. We stimulated $\mathrm{CD}^{+} \mathrm{T}$ cells with IL-23 and IL-1 $\beta$, two cytokines that drive GM-CSF expression in $\mathrm{T}_{\mathrm{H}} 17$ cells $[21,22]$. We found that neither IL-23 nor IL-1 $\beta$ was able to induce STAT5 activation (Figure 3A). Furthermore, IL-1R1 expression was not changed, whereas IL-23R $\alpha$ expression was increased in Stat $^{-/-} \mathrm{CD} 4^{+} \mathrm{T}$ cells (Figure 3B), indicating that STAT5-mediated GM-CSF expression is unlikely dependent on IL-23 and IL- $1 \beta$ signaling. In contrast, both IL- 2 and IL-7 potently activated STAT5 (Figure 3A). Therefore, we further examined the roles of these two cytokines in GM-CSF induction in $\mathrm{CD}^{+} \mathrm{T}$ cells. Splenocytes were isolated from $\mathrm{MOG}_{35-55} / \mathrm{CFA}$-immunized mice before disease onset and challenged with $\mathrm{MOG}_{35-55}$ alone versus in the presence of IL-2 or IL-7 ex vivo. We did not detect an obvious effect of IL-2 on the frequency of GM-CSF-producing cells in $\mathrm{CD} 4^{+} \mathrm{CD} 44^{\mathrm{hi}}$ population (Supplementary information, Figure S8). In contrast, IL-7 significantly increased the frequency of GM-CSF-producing cells in $\mathrm{CD} 4^{+} \mathrm{CD} 44^{\mathrm{hi}}$ population and GM-CSF secretion in a STAT5-dependent manner (Figure $3 \mathrm{C}$ and $3 \mathrm{D})$.

IL-7R $\alpha$ is expressed by naïve and effector $\mathrm{CD}^{+} \mathrm{T}$ cells, suggesting that IL-7 may directly act on both populations to regulate GM-CSF expression. To address this, sorted $\mathrm{CD} 62 \mathrm{~L}^{\text {hi }} \mathrm{CD} 44^{\text {lo }}$ (naïve) and $\mathrm{CD} 62 \mathrm{~L}^{\mathrm{lo}} \mathrm{CD} 44^{\mathrm{hi}}$ (effector) $\mathrm{CD}^{+} \mathrm{T}$ cells from Stat $5^{-/-}$and Stat $^{+/+}$mice during EAE development were activated by anti-CD3 plus anti-CD28 in the presence or absence of IL-7, followed by GM-CSF expression examination. As shown in Figure 3E, CD62 $\mathrm{L}^{\text {lo }} \mathrm{CD} 44^{\mathrm{hi}} \mathrm{T}$ cells expressed GM-CSF more robustly than $\mathrm{CD} 62 \mathrm{~L}^{\text {hi }} \mathrm{CD} 44^{\text {lo }}$ cells. IL-7 promoted 

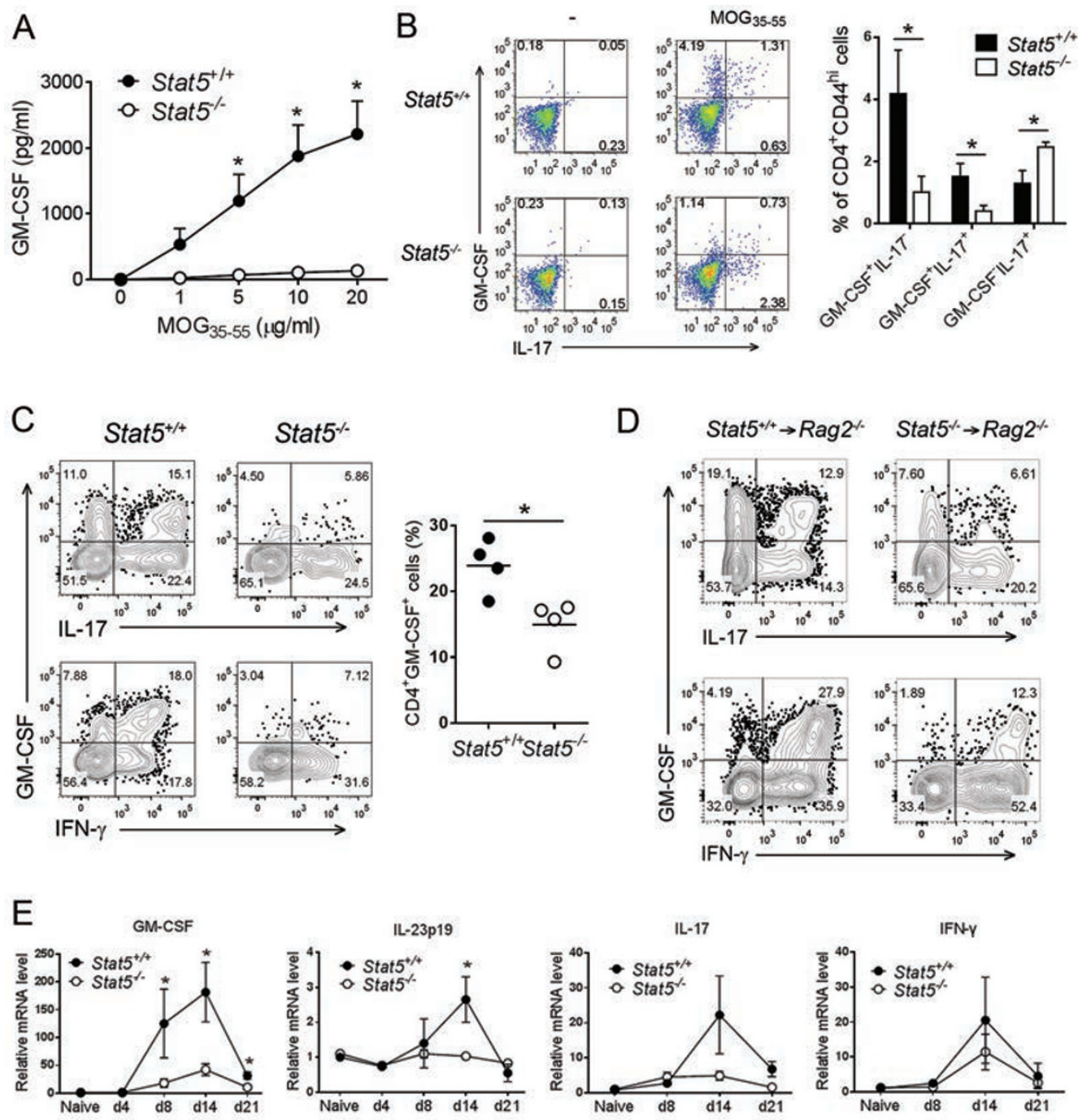

Figure 2 Diminished induction of GM-CSF in Stat5 ${ }^{-/-} \mathrm{CD}^{+}$T cells. (A, B) Splenocytes were obtained from $\mathrm{MOG}_{35-55} / \mathrm{CFA}^{-i m-}$ munized $\mathrm{Stat}^{+/+}$and Stat $5^{-/}$mice ( $n=3$ per group) before disease onset and challenged with $\mathrm{MOG}_{35-55}$ at various concentrations for $24 \mathrm{~h}$. GM-CSF secretion was measured by ELISA (A). Golgiplug was added in the last $4 \mathrm{~h}$ of $\mathrm{MOG}_{35-55}(20 \mu \mathrm{g} / \mathrm{ml})$ challenge and the frequencies of IL- $17^{+}$and $\mathrm{GM}-\mathrm{CSF}^{+}$cells among CD4 ${ }^{+} \mathrm{CD} 44^{\text {hi }} \mathrm{T}$ cells were measured (B). (C) IL-17, IFN- $\gamma$ and GM-CSF expression by CNS-infiltrating CD4 ${ }^{+} \mathrm{T}$ cells of Stat5 $5^{+/+}$and Stat5 ${ }^{-/}$mice was measured by intracellular cytokine staining at peak of disease. (D) IL-17, IFN- $\gamma$, and GM-CSF expression by CNS-infiltrating CD4 ${ }^{+} \mathrm{T}_{\text {cells of }} \mathrm{Rag}^{-/-}$recipient mice at peak of EAE induced by adoptive transfer of $\mathrm{MOG}_{35-55}$-reactive $\mathrm{CD}^{+} \mathrm{T}$ cells. (E) CNS tissues were collected from naïve or $\mathrm{MOG}_{35-55} / \mathrm{CFA}$-immunized mice for RNA extraction ( $n=3$ per group at each time point). Time-course analysis of cytokine mRNA expression was performed with RT-PCR. The RT-PCR data were normalized to Rn18S, and expression in naïve mice was set to 1 . Data represent two independent experiments. ${ }^{*} P<0.05$.

GM-CSF expression in both cell subsets, which was abrogated by STAT5 deficiency (Figure 3E).

Consistent with the facilitating effect of IL-7-dependent T-cell differentiation on EAE, mice treated with an IL-7R $\alpha$-specific antibody (clone SB/14) during EAE development showed a significant reduction of disease severity accompanied with reduced CNS inflammation, but without $\mathrm{T}$ cell depletion [31] (Supplementary informa- tion, Figure S9A-S9C). Notably, blocking IL-7 signaling resulted in decreased GM-CSF expression in CNS-infiltrating $\mathrm{CD}^{+} \mathrm{T}$ cells (Supplementary information, Figure S9D-S9F). These findings demonstrate that IL-7 induces STAT5 activation to promote GM-CSF expression in autoreactive $\mathrm{CD}^{+} \mathrm{T}$ cells, which is critical for the development of neuroinflammation. 
A

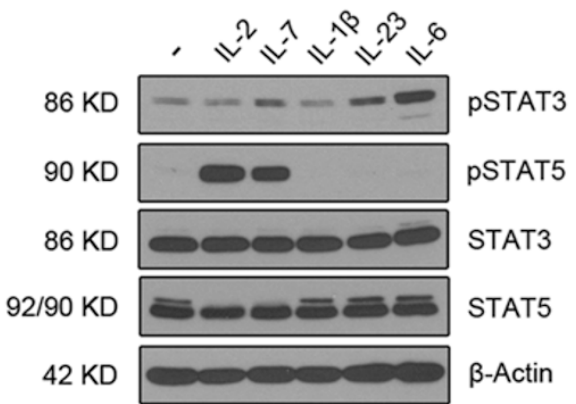

B

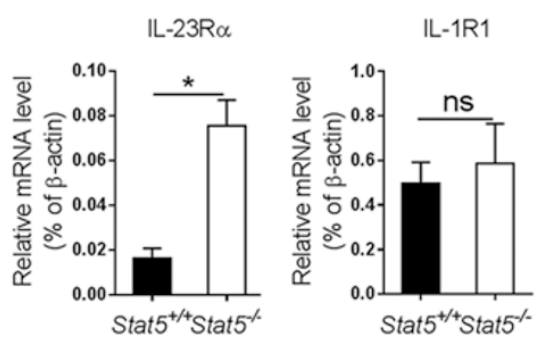

C $\mathrm{MOG}_{35-55} \quad \mathrm{MOG}_{35-55}+\mathrm{IL}-7$
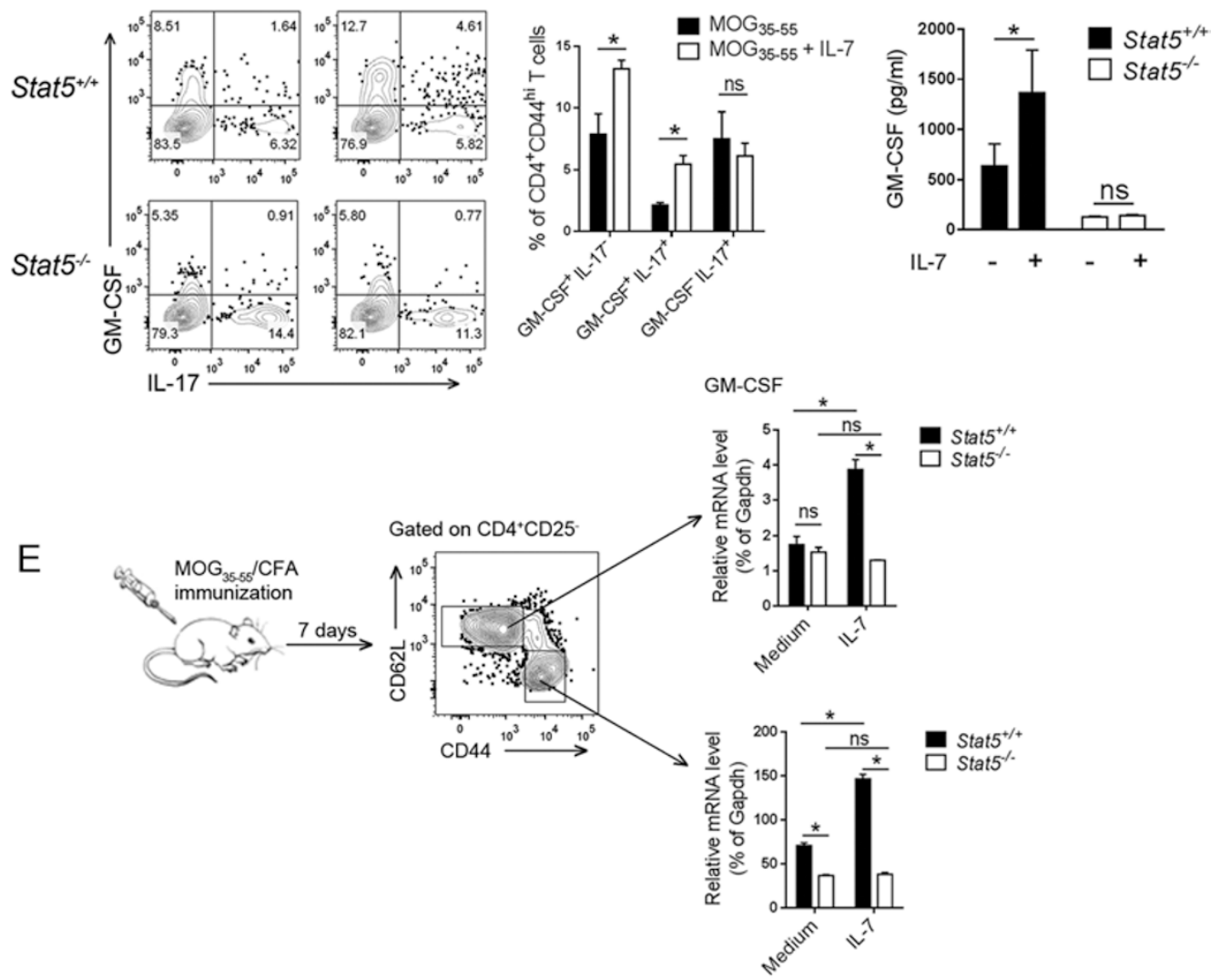

Figure 3 IL-7 promotes GM-CSF expression through STAT5 activation in autoreactive CD4 ${ }^{+}$T cells. (A) Purified CD4 ${ }^{+}$T cells were cultured with TGF- $\beta$ and IL- 6 for 3 days, followed by resting for $6 \mathrm{~h}$. Then cells were treated with various cytokines for 30 min, and pSTAT3 and pSTAT5 levels were determined by immunoblotting. STAT3 and STAT5 were further detected after stripping. (B) The mRNA expression of IL-23R $\alpha$ and IL-1R1 in splenic CD4 ${ }^{+}$T cells of Stat5 $5^{+/}$and Stat5 ${ }^{-/}$EAE mice $(n=3)$. (C, D) Splenocytes were obtained from $\mathrm{MOG}_{35-55} / \mathrm{CFA}$-immunized Stat $5^{+/+}$and Stat $^{-/-}$mice before disease onset and challenged with $\mathrm{MOG}_{35-55}(20 \mu \mathrm{g} / \mathrm{ml})$ in the absence or presence of IL-7 for $48 \mathrm{~h}$. Frequencies of GM-CSF ${ }^{+}$and IL-1 ${ }^{+}$cells among CD4 ${ }^{+}$CD44 ${ }^{\mathrm{hi}}$ T cells were measured by intracellular cytokine staining and flow cytometry (C). Right panel in $\mathbf{C}$ shows overall frequencies of

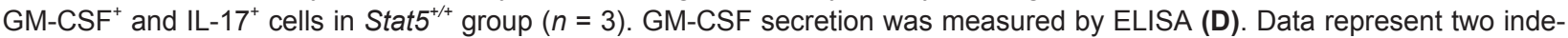
pendent experiments with three mice per group. (E) Splenic CD62L hi CD44 ${ }^{\text {lo }}$ and CD62 ${ }^{\text {lo }} C D 44^{\text {hi }} T$ cells from MOG $35-55 / C F A-i m-$ munized mice were sorted out. Cells were stimulated with anti-CD3 and anti-CD28 in the absence or presence of IL-7 for $4 \mathrm{~h}$ and then harvested for the analysis of GM-CSF expression by RT-PCR. ${ }^{*} P<0.05$; ns, not significant.

$T_{H} 17$ or $T_{H} 1$ differentiation condition inhibits GM-CSF expression

To further understand IL-7/STAT5-mediated GM-CSF expression in $\mathrm{CD}^{+} \mathrm{T}$ cells, we stimulated naïve $\mathrm{CD} 4^{+}$ $\mathrm{T}$ cells with various conditions. We found that anti-CD3 together with anti-CD28 induced the expression of both 
GM-CSF and IFN- $\gamma$ (Supplementary information, Figure S10A). Interestingly, both $\mathrm{T}_{\mathrm{H}} 1$ (IL-12 + anti-IL-4) and $\mathrm{T}_{\mathrm{H}} 17$ (blocking both IFN- $\gamma$ and IL-4 in combination with TGF- $\beta$ + IL-6 or IL- 6 + IL- 23 + IL-1 $\beta$ ) differentiation conditions greatly suppressed the expression of GM-CSF (Figure 4A and 4B). Conversely, neutralization of both IL-12 and IFN- $\gamma$ promoted the generation of GM-CSF-producing cells, consistent with a previous report [21], which was not affected by IL-23 and IL-1 $\beta$ (Figure 4A). In addition to TGF- $\beta$-mediated inhibition of GM-CSF expression [22], we found that IL-6, an essential cytokine for $\mathrm{T}_{\mathrm{H}} 17$ differentiation, had a profound inhibitory effect on GM-CSF expression (Figure 4C), indicating that STAT3 could be a negative regulator of GMCSF expression. We used STAT3-deficient $\mathrm{CD}^{+}{ }^{+} \mathrm{T}$ cells to test this hypothesis. As expected, naïve Stat $^{-/-} \mathrm{CD}^{+}$ $\mathrm{T}$ cells were impaired in $\mathrm{T}_{\mathrm{H}} 17$ differentiation (Supplementary information, Figure S10B). In WT cells, $\mathrm{T}_{\mathrm{H}} 17$ differentiation condition (anti-IFN- $\gamma+$ anti-IL-4 + IL-6 + IL-23 + IL-1 $\beta$ ) greatly inhibited GM-CSF expression (Figure 4A). However, deficiency of STAT3 abrogated the inhibitory effect of IL-6 on GM-CSF expression (Supplementary information, Figure S10B). Interestingly, even without exogenous IL-6, STAT3 exhibited a suppressive effect on GM-CSF expression as Stat $3^{-/}$ cells showed increased GM-CSF expression compared to WT cells (Supplementary information, Figure S10B). In addition, GM-CSF expression in $\mathrm{CD}^{+} \mathrm{T}$ cells is independent of ROR $\gamma t$ and T-bet [22]. Thus, our data support that differentiation of GM-CSF-producing $\mathrm{CD} 4^{+} \mathrm{T}$-cell is distinct from $\mathrm{T}_{\mathrm{H}} 1$ or $\mathrm{T}_{\mathrm{H}} 17$.

\section{IL-7-STAT5 promotes GM-CSF-producing $T_{H^{-}}$cell differ- entiation}

Our findings above suggest the possibility of a potential new $T_{H}$ cell subset that is regulated by IL-7-STAT5 signaling. To further test this possibility, we investigated GM-CSF-producing $\mathrm{T}_{\mathrm{H}}$ cell differentiation in vitro by activating naïve $\mathrm{CD} 4^{+} \mathrm{T}$ cells with anti-CD3 and anti-CD28 in the presence of different concentrations of IL-7. We found that addition of $0.5 \mathrm{ng} / \mathrm{ml} \mathrm{IL-7} \mathrm{greatly}$ increased the frequency of GM-CSF-producing cells and the secretion of GM-CSF, which were further increased upon increase in IL-7 concentration $(1 \mathrm{ng} / \mathrm{ml})$ (Figure 4D and 4E). Without STAT5, IL-7 was unable to promote the generation of GM-CSF-producing cells (Figure 4F and 4G). Chromatin immunoprecipitation (ChIP) analysis showed that IL-7 activated STAT5 directly bound to promoter regions of the $C s f 2$ gene (Supplementary information, Figure S11A and S11B). We noticed the presence of a small proportion of IFN- $\gamma$-producing cells in this condition (Figure 4D). Therefore, we included IFN- $\gamma$-block- ing antibody in the culture and found that a combination of IL-7 and anti-IFN- $\gamma$ induced the highest frequency of $\mathrm{GM}^{-\mathrm{CSF}^{+}}$cells, where few IL- $17^{+}$or IFN- $\gamma^{+}$cells were detected (Figure $4 \mathrm{H}$ ). Therefore, the in vitro generation of GM-CSF-producing $\mathrm{T}_{\mathrm{H}}$ cells requires the transcription factor STAT5, optimal concentration of IL-7, and IFN- $\gamma$ neutralization in addition to TCR and CD28 signaling.

GM-CSF-producing $T_{H}$ cells represent a potential new subset distinct from $T_{H} 1$ or $T_{H} 17$

To further characterize GM-CSF-producing $\mathrm{T}_{\mathrm{H}}$ cells, we differentiated $T_{H} 1, T_{H} 17$, and GM-CSF-producing $T_{H}$ cells from naïve $\mathrm{CD} 4^{+} \mathrm{T}$ cells in vitro. The expression of ROR $\gamma t$ and T-bet was examined. We found that unlike $\mathrm{T}_{\mathrm{H}} 1$ or $\mathrm{T}_{\mathrm{H}} 17$ cells, the expression of T-bet or ROR $\gamma t$ was minimal in GM-CSF-producing $\mathrm{T}_{\mathrm{H}}$ cells (Figure 5A). Next, we performed microarray analysis to examine gene expression profiles of $\mathrm{T}_{\mathrm{H}} 1, \mathrm{~T}_{\mathrm{H}} 17$, and GM-CSF-producing $T_{H}$ cells. We identified a list of 202 genes preferentially expressed in $\mathrm{T}_{\mathrm{H}} 1$ cells compared with naïve, $\mathrm{T}_{\mathrm{H}} 17$ and GM-CSF-producing $\mathrm{T}_{\mathrm{H}}$ cells, among which IFN- $\gamma$, Gzmb, and T-bet were on the top of the list (Figure 5B, left panel and Supplementary information, Table S1). Similarly, $\mathrm{T}_{\mathrm{H}} 17$ feature genes, including IL-17, IL$17 \mathrm{~F}, \mathrm{ROR} \gamma \mathrm{t}$, and ROR $\alpha$, were identified in the list of 411 genes specific to $\mathrm{T}_{\mathrm{H}} 17$ cells (Figure 5B, middle panel, and Supplementary information, Table S1). The GM-CSF-producing $\mathrm{T}_{\mathrm{H}}$ cell-specific gene list contains 210 genes with genes encoding GM-CSF and IL-3 as the top genes in the list (Figure 5B, right panel and Supplementary information, Table S1).

Next, we further verified the microarray findings. Cytokine expression analysis showed that GM-CSF was predominately expressed in GM-CSF-producing $\mathrm{T}_{\mathrm{H}}$ cells compared with $\mathrm{T}_{\mathrm{H}} 1$ or $\mathrm{T}_{\mathrm{H}} 17$ cells (Figure 5C and 5D). Interestingly, IL-3, a cytokine that is coregulated with GMCSF [32], was also highly expressed in GM-CSF-producing $T_{H}$ cells, not $T_{H} 1$ or $T_{H} 17$ cells (Figure 5D). Further examination showed that IL-3 expression was also regulated by IL-7-STAT5 signaling (Figure 5E and 5F).

IL-2, which also signals through STAT5, did not promote GM-CSF-producing $\mathrm{T}_{\mathrm{H}}$ differentiation (Supplementary information, Figure S12A), possibly due to the lack of IL-2R $\alpha$ expression on naïve $\mathrm{CD} 4^{+} \mathrm{T}$ cells and thus the unresponsiveness of STAT5 to the IL-2 signal early in differentiation (Supplementary information, Figure S12B-S12D). To further confirm this possibility, we stimulated activated $\mathrm{CD} 4^{+} \mathrm{T}$ cells with IL-2 or IL7, and found both cytokines induced STAT5 activation, STAT5 binding to Csf2 promoter, and increase in GMCSF mRNA levels (Supplementary information, Figure S13A-S13C). Notably, IL-2 induced a prolonged STAT5 
A

$\alpha-I F N-\gamma+\alpha-I L-4$ $\alpha-I L-12+\alpha-I F N-y$
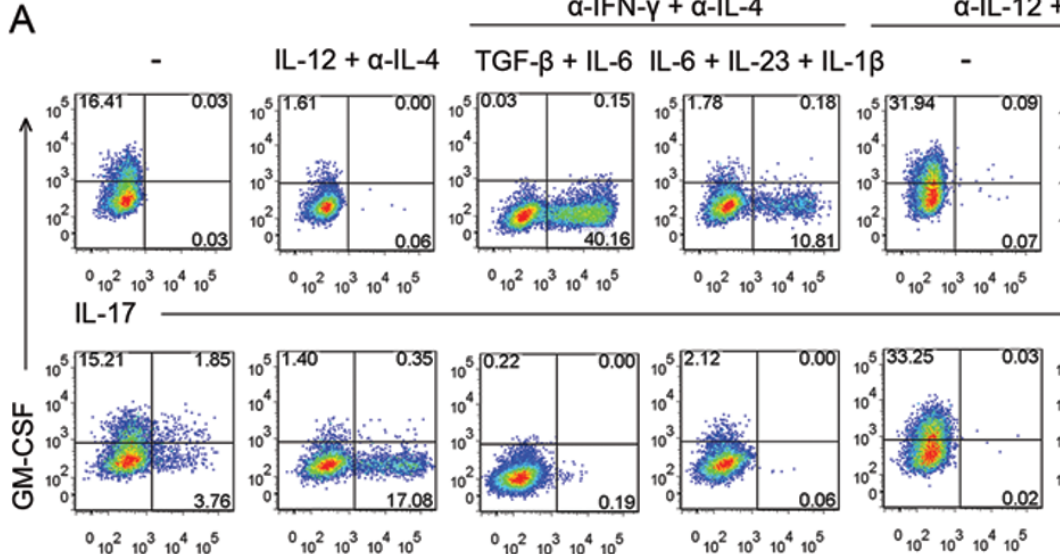

$\mathrm{IL}-23+\mathrm{IL}-1 \beta$
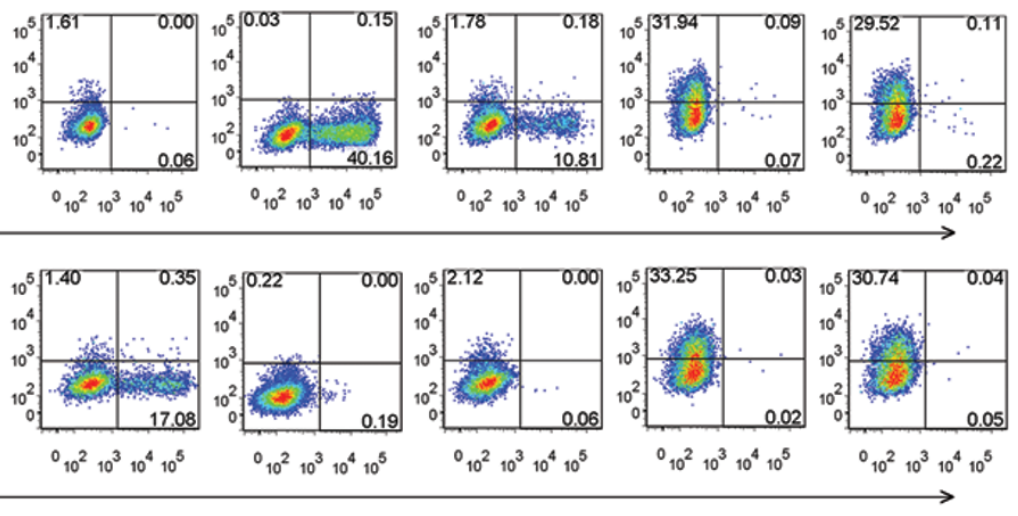

B

$$
\mathrm{IFN}-\gamma
$$

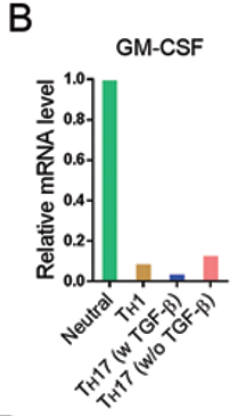

C

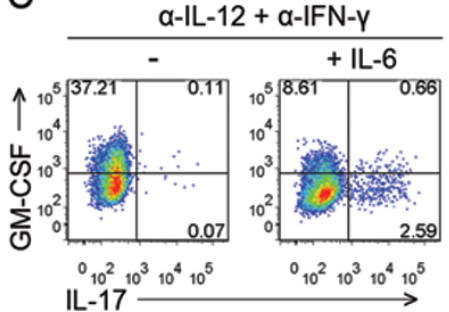

$\mathrm{E}$
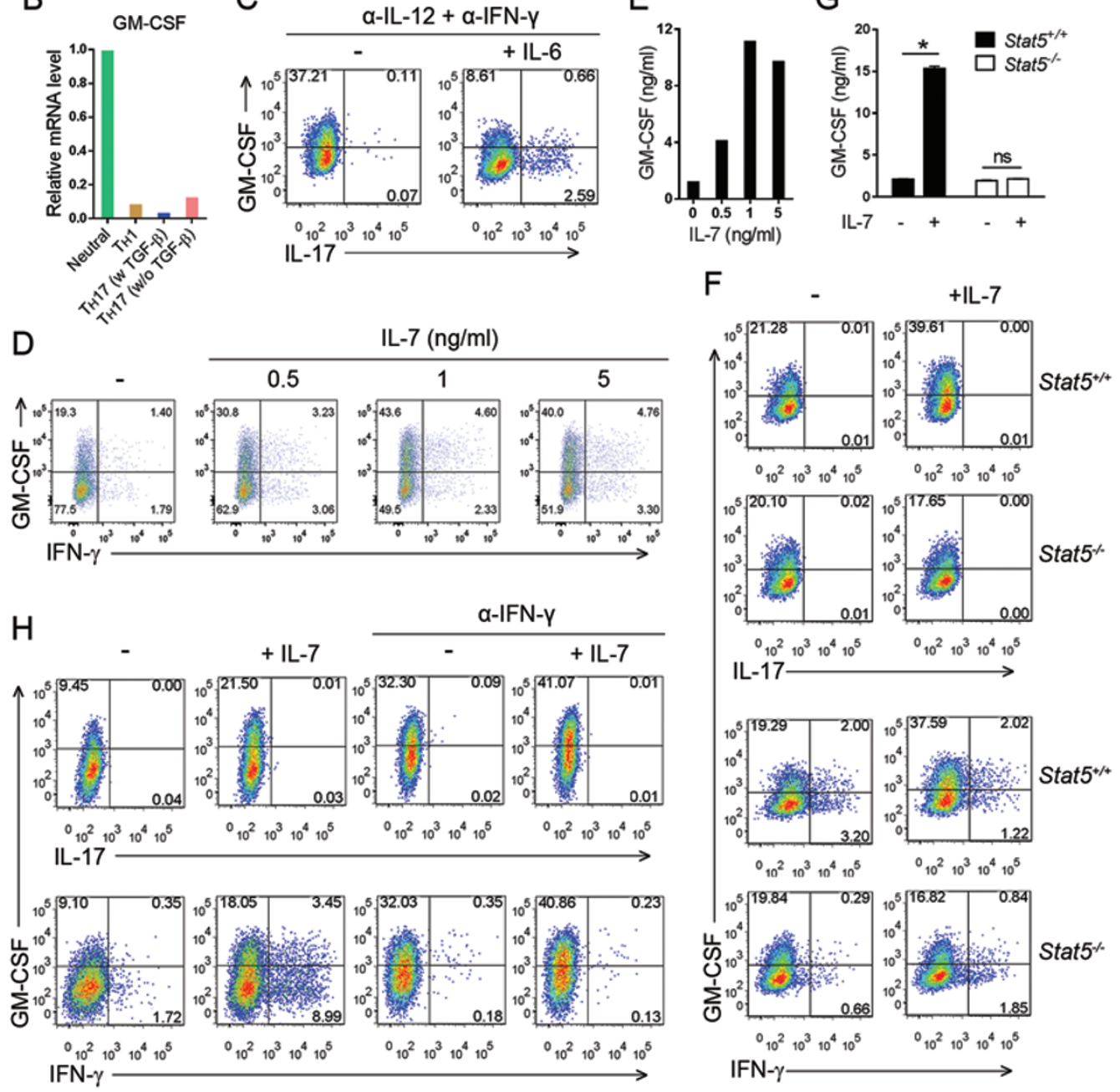

Figure 4 Regulation of GM-CSF-producing $T_{H}$ cells in vitro. (A-E) Naïve $C D 4^{+} T$ cells were primed with plate-bound anti-CD3 and soluble anti-CD28 in the presence of a combination of various cytokines and neutralizing antibodies as indicated. GMCSF, IL-17, and IFN- $\gamma$ expression was analyzed by intracellular cytokine staining (A, C, D), RT-PCR (B) or ELISA (E). (F, G) $\mathrm{Stat5}^{+/ /}$and $\mathrm{Stat5}^{-/-}$naïve CD4 ${ }^{+}$T cells were activated with anti-CD3 and anti-CD28 in the presence IL-7 for 3 days. GM-CSF, $\mathrm{IL}-17$, and IFN- $\gamma$ expression was analyzed by intracellular cytokine staining (F). GM-CSF secretion was measured by ELISA (G). (H) Naïve CD4 ${ }^{+}$T cells were activated with anti-CD3 and anti-CD28 in the presence of IL-7 or/and anti-IFN- $\gamma$ as indicated. GM-CSF, IL-17, and IFN- $\gamma$ expression was analyzed. Data represent more than two independent experiments. ${ }^{*} P<0.05$; ns, not significant. 
A
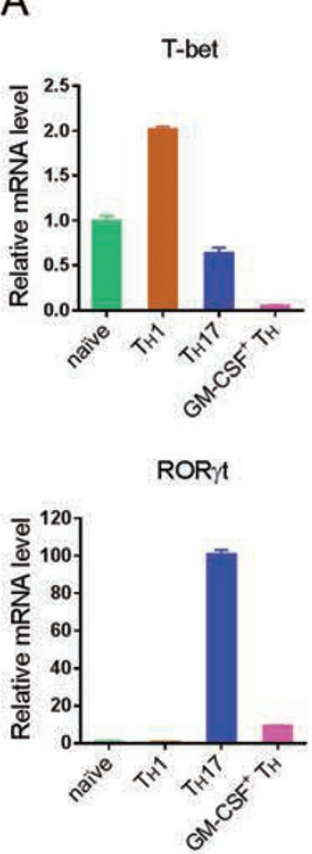

C

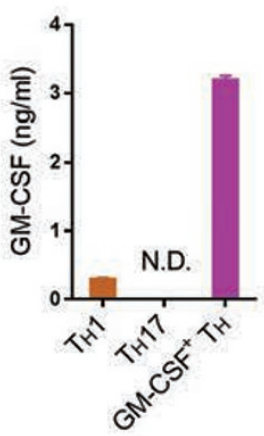

D
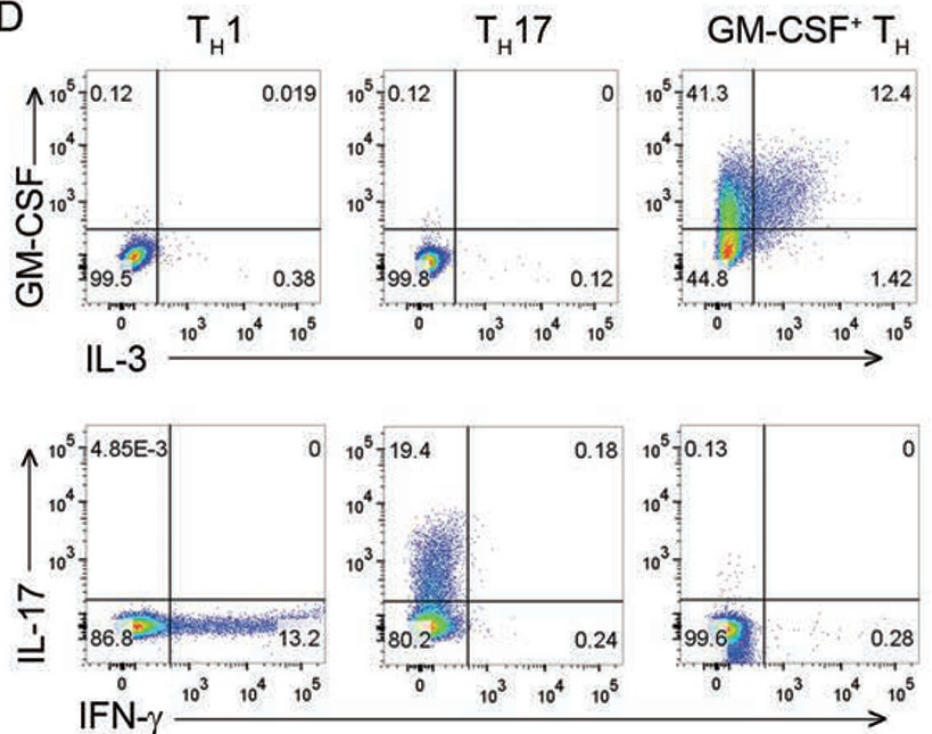

B

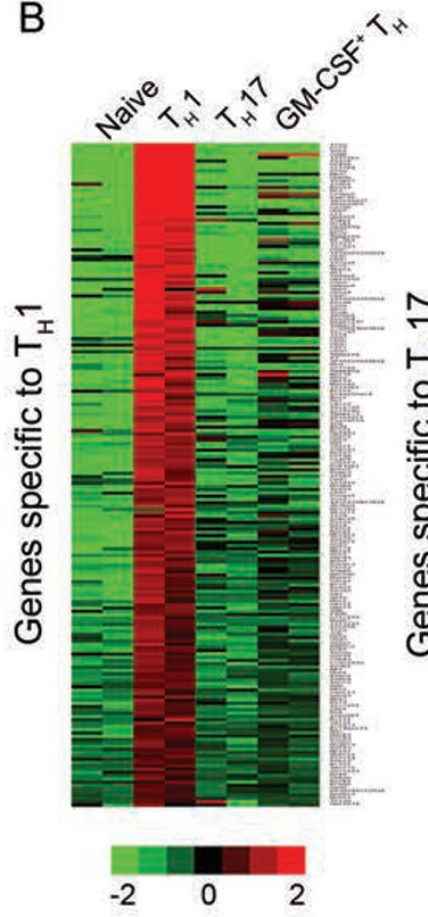

E

IL-7

$\mathrm{F}$

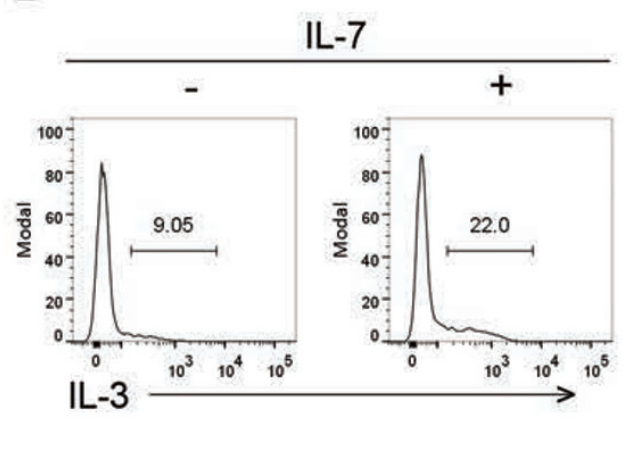

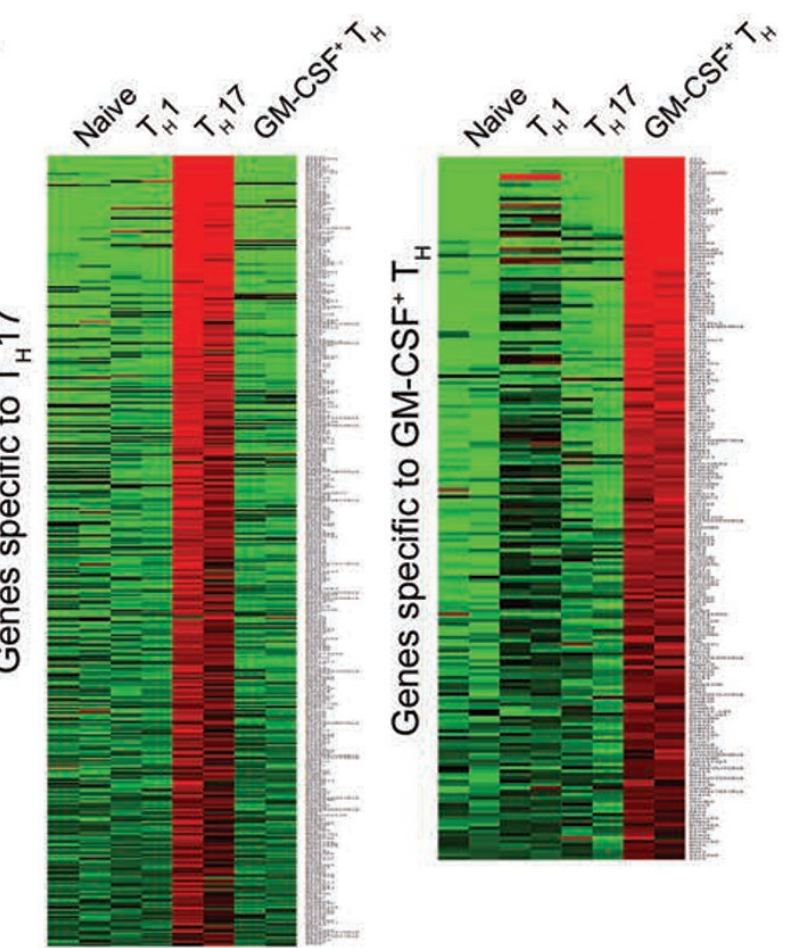
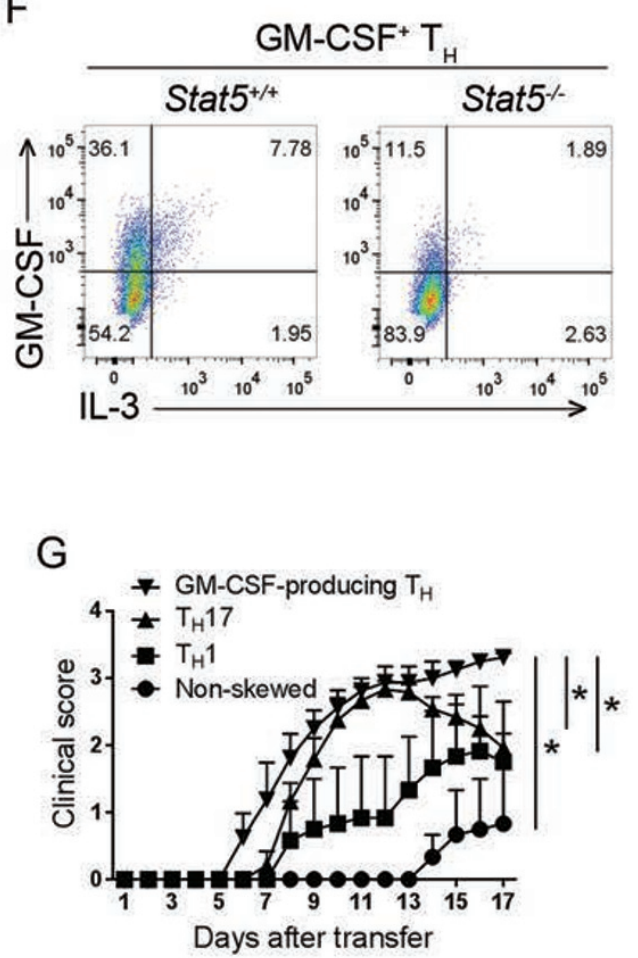
activation compared with IL-7 (Supplementary information, Figure S13A).

To test the hypothesis that the GM-CSF-producing $T_{H}$ subset is the primary encephalitogenic effector cells, we performed adoptive transfer of different subsets of $\mathrm{MOG}_{35-55}$-reactive $\mathrm{CD}^{+} \mathrm{T}$ cells into $\operatorname{Rag}^{-/-}$mice for EAE induction. As shown in Figure 5G, GM-CSF-producing $\mathrm{T}_{\mathrm{H}}$ cells were preferentially able to induce a more robust EAE compared with $\mathrm{T}_{\mathrm{H}} 17$ and $\mathrm{T}_{\mathrm{H}} 1$ subsets.

Together, these data demonstrate that IL-7-STAT5signaling controls the differentiation of a new $\mathrm{T}$ helper cell subset that is distinct from $\mathrm{T}_{\mathrm{H}} 1$ or $\mathrm{T}_{\mathrm{H}} 17$ and predominantly expresses GM-CSF and IL-3.

STAT5-deficient $C D 4^{+} T$ cells retain the capacity to induce colitis

The finding from the EAE model prompted us to test whether STAT5-deficient T cells also lacked pathogenicity in other T cell-mediated autoimmune diseases. We assessed the pathogenic potential of STAT5-deficient autoreactive $\mathrm{CD}^{+} \mathrm{T}$ cells in colitis by reconstituting $\mathrm{Rag}^{-/-}$ mice with Stat $^{-/-}$, Stat $5^{-/}$or WT CD $4^{+} \mathrm{CD} 25^{-} \mathrm{CD} 45 \mathrm{RB}^{\text {hi }}$ naïve $\mathrm{T}$ cells. Consistent with a previous report [33], mice reconstituted with Stat $^{-1-}$ T cells continued to gain weight, whereas mice receiving Stat $^{-/-}$or WT T cells lost weight (Figure 6A), and showed enlarged spleens and mesenteric lymph nodes (MLNs) (Figure 6B). Marked colonic inflammation and inflammatory cell infiltration in the colon were observed in mice that received either WT or Stat $5^{-/-}$T cells at 8 weeks after reconstitution (Figure 6C and 6D). Consistent with the resistance to colitis in mice receiving $S t a t 3^{-/-}$cells, an obviously reduced frequency of $\mathrm{CD}^{+} \mathrm{T}$ cells and IL-17-producing $\mathrm{CD} 4^{+} \mathrm{T}$ cells in their lamina propria lymphocytes (LPLs) was observed compared with mice receiving Stat $5^{-/}$ or WT cells (Figure 6D and 6E). There was no defect in either IL-17 or IFN- $\gamma$ production by $\mathrm{CD}^{+} \mathrm{T}$ cells in LPLs of mice reconstituted with Stat $5^{-/-}$T cells (Figure $6 \mathrm{E}$ ). However, we detected a significant reduction in GM-CSF-producing T cells in the absence of STAT5 when transferred into $\operatorname{Rag}^{-/-}$mice (Figure 6E). There- fore, GM-CSF-producing $\mathrm{CD}^{+} \mathrm{T}$ cells might not play a critical role in colitis. This view was further supported by the observation that although there were comparable $\mathrm{GM}^{-\mathrm{CSF}^{+}}$cells in $\mathrm{Stat}^{-/-}$and WT-transferred T cells, $\mathrm{Stat}^{-/-} \mathrm{CD} 4^{+} \mathrm{T}$ cells failed to induce colitis.

\section{Discussion}

Effector $\mathrm{T}_{\mathrm{H}}$ cells, differentiated from naïve $\mathrm{T}$ cells after TCR-mediated antigen recognition with the influence of costimulation and the instruction from specific cytokines, are classified by their specific cytokine expression and immune-modulatory functions $[1,3,34]$. Here we have demonstrated that IL-7, signaling through STAT5, induces the development of a potential new $\mathrm{T}_{\mathrm{H}}$ subset that predominantly expresses GM-CSF (GM-CSF-producing $\mathrm{T}_{\mathrm{H}}$ cells). In addition to GM-CSF, we identified that this $\mathrm{T}_{\mathrm{H}}$ subset highly expresses IL-3, a cytokine important in regulating the function of myeloid-derived immune cells. The development of GM-CSF-producing $T_{H}$ cells is independent of the mechanisms required for $T_{H} 1$ or $T_{H} 17$ development. In fact, conditions for $\mathrm{T}_{\mathrm{H}} 1$ or $\mathrm{T}_{\mathrm{H}} 17$ differentiation suppressed the development of GM-CSF-producing $\mathrm{T}_{\mathrm{H}}$ cells. It is known that differentiated effector $\mathrm{T}_{\mathrm{H}}$ cells could produce specific cytokines to create a cytokine environment that favors the differentiation of their own while suppressing the differentiation of other $T_{H}$ subsets. For instance, IL-12 as well as IFN- $\gamma$ induces $T_{H} 1$ differentiation. The differentiated $\mathrm{T}_{\mathrm{H}} 1$ cells produce large amounts of IFN- $\gamma$ to amplify $\mathrm{T}_{\mathrm{H}} 1$ differentiation, whereas they suppress $\mathrm{T}_{\mathrm{H}} 17$ or GM-CSF-producing $\mathrm{T}_{\mathrm{H}}$ differentiation. It is possible that the GM-CSF-producing $\mathrm{T}_{\mathrm{H}}$ cells produce certain cytokines to promote the differentiation of their own, but suppress the differentiation of $\mathrm{T}_{\mathrm{H}} 1 \mathrm{and} /$ or $\mathrm{T}_{\mathrm{H}} 17$ cells. It is also possible that this new subset of $\mathrm{T}_{\mathrm{H}}$ cells produce cytokines such as GM-CSF to enhance $\mathrm{T}_{\mathrm{H}} 1$ or $\mathrm{T}_{\mathrm{H}} 17$ responses via inducing the production of inflammatory cytokines from myeloid cells. Further studies are needed to explore such possibilities.

While this manuscript was under submission, a report was published, showing that IL-17 and GM-CSF expres-

Figure 5 Distinct features of GM-CSF-producing $T_{H}$ cells. (A) The mRNA expression of T-bet and ROR $\gamma \mathrm{t}$ in naïve, $\mathrm{T}_{H} 1$ (IL$12+$ anti-IL-4), $\mathrm{T}_{\mathrm{H}} 17$ (TGF- $\beta+$ IL-6 + anti-IFN- $\gamma+$ anti-IL-4) and GM-CSF-producing $\mathrm{T}_{\mathrm{H}}$ (IL-7 + anti-IFN- $\gamma$ ) cells. The RT-PCR data were normalized to Gapdh, and expression in naïve T cells was set to 1. (B) Naïve CD4 ${ }^{+}$T cells were differentiated into $\mathrm{T}_{\mathrm{H}} 1, \mathrm{~T}_{\mathrm{H}} 17$ and GM-CSF-producing $\left(\mathrm{GM}^{-C S F^{+}}\right) \mathrm{T}_{\mathrm{H}}$ cells in vitro. Microarray analysis was performed to examine their gene expression profiles. Hierarchical clusters of preferentially expressed genes for $T_{H} 1, T_{H} 17$, or GM-CSF-producing $T_{H}$ cells were shown (biological duplication). (C) GM-CSF secretion by three $T_{H}$ subsets in vitro. (D) Flow cytometric analysis of cytokine expression (GM-CSF, IL-3, IL-17, and IFN- $\gamma$ ) by three $\mathrm{T}_{\mathrm{H}}$ subsets in vitro. (E) Frequency of IL- $3^{+}$cells generated with or without IL-7. (F) GM-CSF and IL-3 expression by WT or STAT5-deficient GM-CSF-producing $T_{H}$ cells. (G) Clinical EAE scores of Rag $2^{-/-}$mice ( $n=3-6$ mice per group) after adoptive transfer of $6 \times 10^{5}$ various $M O_{35-55}$-reactive $T_{H}$ subsets. Data represent two independent experiments. ${ }^{*} P<0.05$. 
A

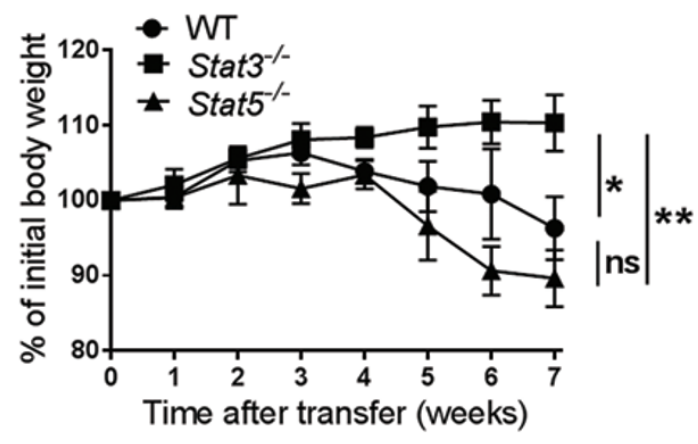

B

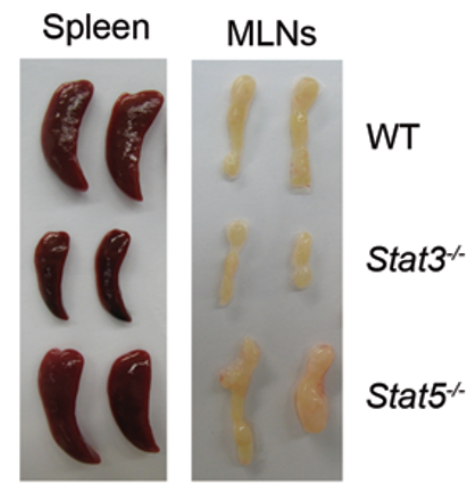

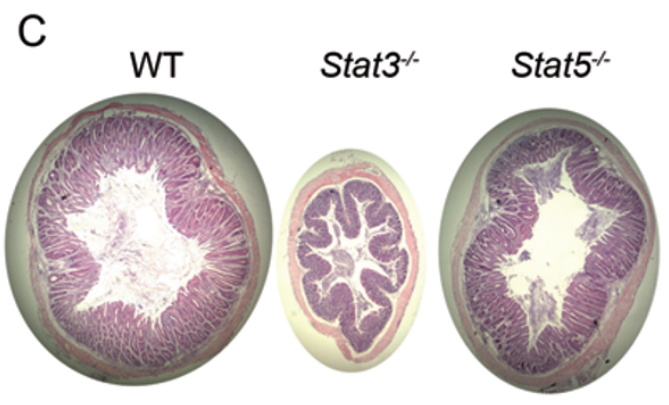

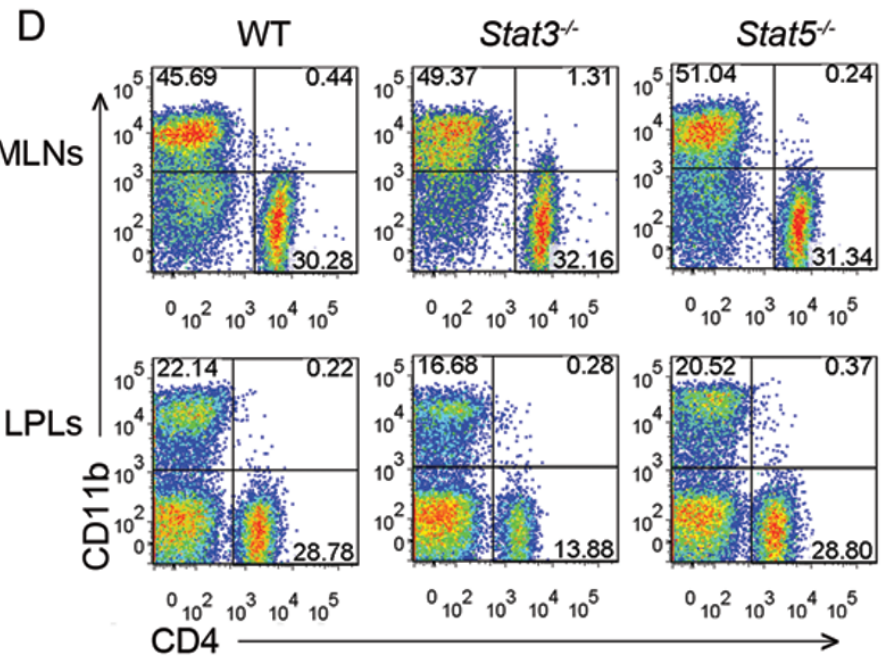

E
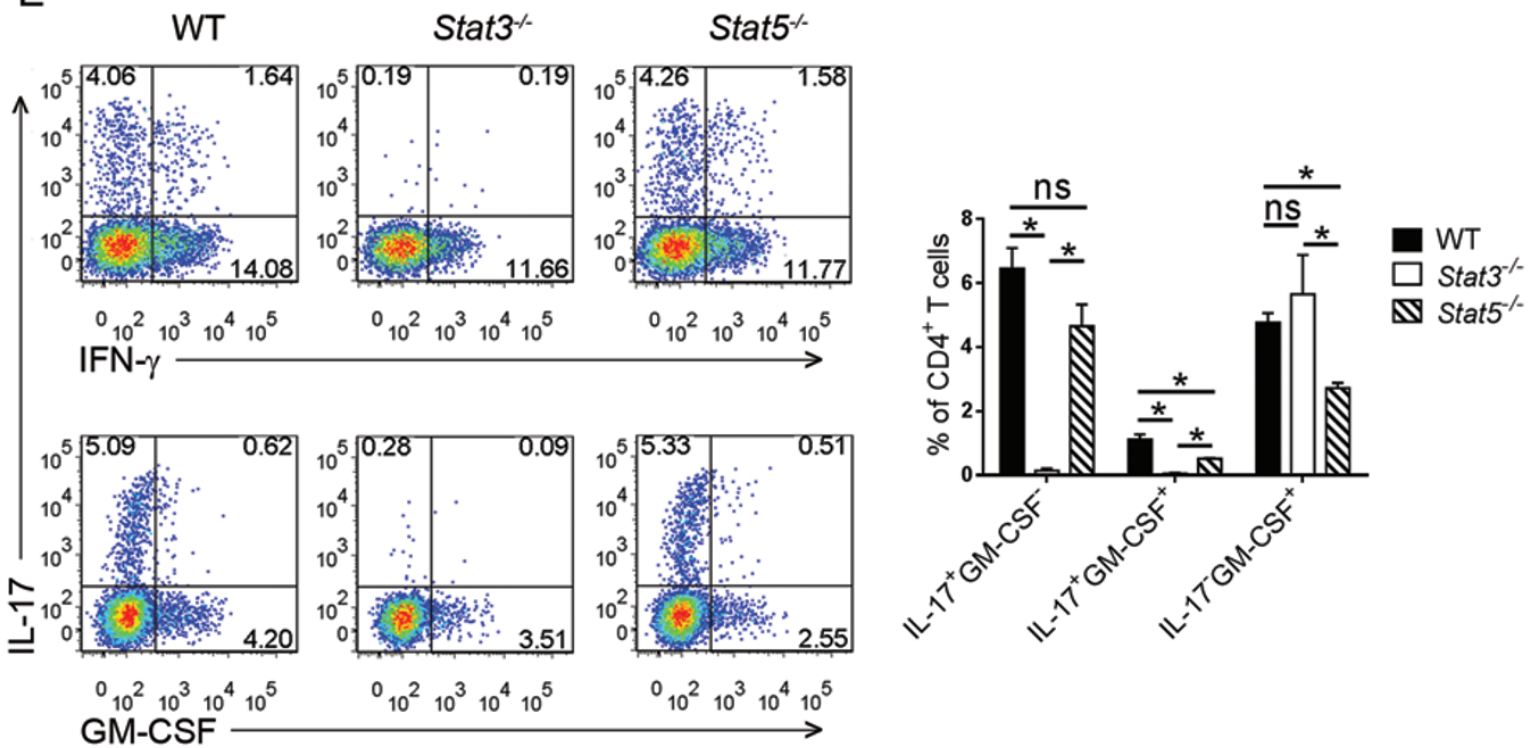

Figure 6 STAT5 is not required in T cell-dependent colitis. (A) Rag $2^{-/-}$mice were reconstituted with $\mathrm{CD}^{+} \mathrm{CD} 25^{-} \mathrm{CD} 45 \mathrm{RB} \mathrm{B}^{\mathrm{hi}}$ naïve T cells derived from WT, Stat $3^{-/-}$or Stat5 $5^{-/}$mice (3-5 mice per group). Body weight loss was monitored and calculated over 7 weeks. Data are representative of two independent experiments. (B) Systemic inflammation was assessed by comparing size of spleen and MLNs 8 weeks after transfer. (C) Colonic inflammation was assessed histologically. Images shown are representative of three mice per group. (D) Percentages of CD4 $4^{+}$T cells and CD11 $\mathrm{b}^{+}$cells in MLNs and LPLs were analyzed by flow cytometry. Data are representative of at least three mice per group. (E) IL-17, IFN- $\gamma$, and GM-CSF production by $\mathrm{CD}^{+} \mathrm{T}$ cells in LPLs was measured. ${ }^{*} P<0.05,{ }^{* *} P<0.005$. 
sion in human $\mathrm{T}_{\mathrm{H}}$ cells are antagonistically regulated [35]. Similar to our finding in mice, Noster et al. [35] found that GM-CSF-producing $\mathrm{T}_{\mathrm{H}}$ cells represent a substantial population in the cerebrospinal fluid of MS patients, suggesting a pathogenic role of these cells in neuroinflammation. Our work utilizing the mouse model for a thorough functional study has provided clear genetic evidence showing the essential role of STAT5 in GM-CSF and IL-3 production in this novel $\mathrm{T}_{\mathrm{H}}$ cell subset. This subset is essential, even in the context of normal $\mathrm{T}_{\mathrm{H}} 1$ or $\mathrm{T}_{\mathrm{H}} 17$ activity, for the pathogenesis of EAE. We propose to tentatively refer to this $\mathrm{T}$ helper cell subset as $\mathrm{T}_{\mathrm{H}}$-GM, which is critically regulated by STAT5 and predominantly produces GM-CSF and IL-3.

GM-CSF governs the activities of myeloid-derived cell populations and is implicated in various inflammatory and autoimmune diseases such as rheumatoid arthritis (RA) and MS. Therapeutic interventions targeting GMCSF, such as Mavrilimumab (human anti-GM-CSFR $\alpha$ $\mathrm{Ab}$ ) and MOR103 (human anti-GM-CSF mAb), are under phase 2 clinical trial in RA and RA/MS, respectively (clinicaltrials.gov). IL-3 is a cytokine also involved in several autoimmune diseases [36-39]. Therefore, directly targeting this new subset of $\mathrm{T}_{\mathrm{H}}$ cells, the dominant source of such pathogenic mediators, in various autoimmune diseases could lead to better outcomes than targeting a single factor, such as GM-CSF or IL-3.

STAT5 transmits IL-2 signals. A previous widely accepted model is that T-cell survival and proliferation require IL-2, based on studies using in vitro systems. There is now much evidence arguing that IL-2 is dispensable for the induction of $\mathrm{T}$ cell-dependent immunity in vivo [40]. In our EAE model, we indeed observed Stat5-conditional knockout mice had fewer $\mathrm{CD}^{+} \mathrm{T}$ cells in the CNS after disease onset as STAT5-deficient $\mathrm{CD} 4^{+} \mathrm{T}$ cells had inability to induce effective inflammatory responses. However, in EAE induced by $\mathrm{CD}^{+} \mathrm{T}$ cell transfer, STAT5-deficient $\mathrm{CD} 4^{+} \mathrm{T}$ cells with a number comparable to that of WT cells in the CNS still failed to induce the disease (Supplementary information, Figure S6A and S6B). These results suggest that the role of STAT5 in $\mathrm{CD}^{+} \mathrm{T}$ cell survival and proliferation is unlikely the major causal factor of EAE resistance in Stat5-conditional knockout mice.

IL-7, signaling through the common $\gamma \mathrm{c}$ and IL-7R $\alpha$, is required for $\mathrm{T}$ cell homeostasis [41]. A previous report showed that IL-7 could acutely stimulate GM-CSF production from memory $\mathrm{T}$ cells [42]. Here, our work demonstrates that IL-7 through STAT5 activation induces the generation of pathogenic $\mathrm{T}_{\mathrm{H}^{-}} \mathrm{GM}$ cells for GMCSF production in mediating neuroinflammation. Our finding is in line with the association of IL-7R $\alpha$ variants with MS in patient GWAS and the beneficial effect of IL-7R $\alpha$-neutralizing antibody in EAE treatment [43-45]. A recent report indicates IL-7 promotes IFN- $\gamma$ production by $T_{H} 1$ cells and contributes to a $T_{H} 1$-driven subtype of MS [45]. However, mice deficient in IFN- $\gamma$ show exacerbated EAE development [15]. Thus, the requirement for IL-7 in EAE development is unlikely due to its role in promoting IFN- $\gamma$ production.

The function of IL-23, a cytokine required for $T_{H} 17$ terminal differentiation [46], in EAE suggests the involvement of $\mathrm{T}_{\mathrm{H}} 17$ cells in this disease [16]. However, the major cytokines produced by $\mathrm{T}_{\mathrm{H}} 17$ cells, IL-17A, IL$17 \mathrm{~F}$, and IL-22, were found to be dispensable for the development of EAE $[19,20]$. However, IL-23 was found to induce the expression of GM-CSF in $\mathrm{T}_{\mathrm{H}} 17$ cells, a factor essential for encephalitogenicity of $\mathrm{T}$ cells [21, 22], which seems to strengthen the link between $T_{H} 17$ cells and EAE. Paradoxically, a recent study reported IL-23/ ROR $\gamma \mathrm{t}$ axis-suppressed GM-CSF expression in human $\mathrm{T}_{\mathrm{H}}$ cells [35]. Moreover, anti-IL-23 receptor antibodies that worked well for treating peripheral inflammation such as psoriasis failed in treating MS [47], suggesting that the function of IL-23 in MS could be compensated by other factors. In this study, we found that $\mathrm{T}_{\mathrm{H}}$-GM cells produced greater amounts of GM-CSF than $\mathrm{T}_{\mathrm{H}} 1$ or $\mathrm{T}_{\mathrm{H}} 17$ cells (Figure 5), suggesting that $\mathrm{T}_{\mathrm{H}}$-GM cells are the major source of GM-CSF in T cell-mediated neuronal inflammation. Interestingly, we found that the expression of IL-23p19 in CNS during EAE development only occurred after the onset of the disease and Stat 5 gene deletion in $\mathrm{T}$ cells abolished its expression (Figure 2E), suggesting that IL-23 is not required for the initiation of EAE and signaling transduced by STAT5 is required for IL-23 expression in CNS in neuronal inflammation. It is possible that GM-CSF-producing $\mathrm{T}_{\mathrm{H}}$-GM cells provide GM-CSF to induce the expression of IL-23 from DCs, macrophages, and other CNS-residential cells to sustain the inflammation. Therefore, our study does not exclude a scenario where GM-CSF-producing $\mathrm{T}_{\mathrm{H}}$-GM cells cooperate with $T_{\mathrm{H}} 1$ and/or $\mathrm{T}_{\mathrm{H}} 17$ to mediate the development of EAE. Further study on $\mathrm{T}_{\mathrm{H}}$-GM cells including their physiological functions is warranted for targeting these cells for the development of therapeutic interventions for human inflammatory diseases such as MS.

It is interesting to see that STAT5-regulated $\mathrm{T}_{\mathrm{H}}$-GM cells are not required in a T-cell transfer model of colitis (Figure 6). EAE represents sterile CNS inflammation, in which autoreactive $\mathrm{CD} 4^{+} \mathrm{T}$ cells are the major producers of GM-CSF, a factor crucial for EAE pathogenesis [23]. However, numerous inflammatory cytokines, such as $\mathrm{T}_{\mathrm{H}} 1$-related IFN- $\gamma$ and $\mathrm{T}_{\mathrm{H}} 17$-related IL-17F, are implicated in the pathogenesis of colitis [48]. STAT5-deficient 
CD4 $4^{+} \mathrm{T}$ cells are not impaired in $\mathrm{T}_{\mathrm{H}} 1$ or $\mathrm{T}_{\mathrm{H}} 17$ generation. In addition, GM-CSF could be induced in other types of cells in the intestine, such as Paneth cells [49]. Thus, STAT5-mediated GM-CSF production in T cells may not be mandatory for colitis.

In summary, we found that a distinct subset of T helper cells $\left(\mathrm{T}_{\mathrm{H}}-\mathrm{GM}\right)$, which is regulated by IL-7-STAT5 signaling axis and predominantly produces GM-CSF and IL-3, is critical for autoimmune neuroinflammation.

\section{Materials and Methods}

\section{Mice}

Stat $5^{f f f}$ mice were provided by L Hennighausen (National Institute of Diabetes and Digestive and Kidney Diseases) [27]. Stat $3^{\text {fff }}$ mice were generated as described [50]. Cd4-Cre transgenic mice were purchased from Taconic Farms. Rag $2^{-/-}$mice were obtained from Jean-Pierre Abastado (Singapore Immunology Network). All mice are on a C57BL/6 genetic background and housed under specific-pathogen-free conditions at the National University of Singapore. All experiments were performed with 6-8-week-old mice and approved by the Institutional Animal Care and Use Committee of NUS.

\section{In vitro T-cell differentiation}

$\mathrm{CD} 4^{+} \mathrm{T}$ cells were obtained from spleens and lymph nodes by positive selection and magnetic separation (Miltenyi Biotec), followed by purification of naïve $\mathrm{CD} 4^{+} \mathrm{T}$ cell population $\left(\mathrm{CD} 4^{+} \mathrm{CD} 25^{-}\right.$ CD62 $\mathrm{L}^{\text {hi }} \mathrm{CD} 44^{\text {lo }}$ ) sorted with FACS Aria. Naïve CD4 ${ }^{+} \mathrm{T}$ cells were stimulated with plate-bound anti-CD3 ( $3 \mu \mathrm{g} / \mathrm{ml}$; BD Pharmingen) and anti-CD28 (1 $\mu \mathrm{g} / \mathrm{ml}$; BD Pharmingen $)$ in the presence of different combinations of neutralizing antibodies and cytokines for 3-4 days: for neutral conditions, no addition of any cytokine or neutralizing antibody; for $\mathrm{T}_{\mathrm{H}} 1$ conditions, IL-12 $(10 \mathrm{ng} / \mathrm{ml})$, and anti-IL-4 (10 $\mu \mathrm{g} / \mathrm{ml}$, BD Pharmingen); for $\mathrm{T}_{\mathrm{H}} 17$ conditions, hTGF- $\beta$ (3 ng/ml), IL-6 (20 ng/ml), anti-IFN- $\gamma(10 \mu \mathrm{g} / \mathrm{ml}$, eBioscience), and anti-IL-4 $(10 \mu \mathrm{g} / \mathrm{ml})$; for an alternative $\mathrm{T}_{\mathrm{H}} 17$ conditions, IL-6 (20 ng/ml), IL-23 (10 ng/ml), IL-1 $\beta$ (10 ng/ml), anti-IFN- $\gamma(10$ $\mu \mathrm{g} / \mathrm{ml})$, and anti-IL-4 $(10 \mu \mathrm{g} / \mathrm{ml})$. For GM-CSF-producing cell differentiation, naïve $\mathrm{CD}^{+} \mathrm{T}$ cells were stimulated with plate-bound anti-CD3 $(3 \mu \mathrm{g} / \mathrm{ml})$ and soluble anti-CD28 $(1 \mu \mathrm{g} / \mathrm{ml})$ with the addition of IL-7 $(2 \mathrm{ng} / \mathrm{ml})$ and/or anti-IFN- $\gamma(10 \mu \mathrm{g} / \mathrm{ml})$ as indicated. All cytokines were obtained from R\&D Systems. All cells were cultured in RPMI 1640 supplemented with 10\% FBS, 100 units/ $\mathrm{ml}$ penicillin, $0.1 \mathrm{mg} / \mathrm{ml}$ streptomycin, $1 \mathrm{mM}$ sodium pyruvate, 0.1 $\mathrm{mM}$ nonessential amino acid and $5 \mu \mathrm{M}$ beta-mercaptoethanol. After polarization for 3-4 days, cells were washed and restimulated with phorbol 12-myristate 13-acetate (PMA) and ionomycin in presence of Golgiplug for 4-5 h, followed by fixation and intracellular staining with a Cytofix/Cytoperm kit from BD Pharmingen. Foxp3 staining was done with a kit from eBioscience. Cells were acquired on the LSR II (BD Biosciences) and analyzed with FlowJo software (Tree Star).

\section{EAE induction}

EAE induction procedures were modified from a previous report [51]. For active EAE induction, mice were immunized in two sites on the hind flanks with $300 \mu \mathrm{g} \mathrm{MOG}_{35-55}$ in $100 \mu \mathrm{l} \mathrm{CFA} \mathrm{con-}$ taining $5 \mathrm{mg} / \mathrm{ml}$ heat-killed M. tuberculosis strain H37Ra (Difco) on day 0 and day 7. Pertussis toxin (List Bio Lab) was administrated intraperitoneally at the dosage of $500 \mathrm{ng}$ per mouse on day 1 and day 8. For single $\mathrm{MOG}_{35-55} / \mathrm{CFA}$ immunization, the similar procedure was performed on day 0 and day 1 only. In an alternative active EAE induction, LPS $(600 \mu \mathrm{g} / \mathrm{ml}$ in IFA, O111:B4 from Sigma) was used as adjuvant. For active EAE induction in $\mathrm{Rag}^{-/}$ mice, $\mathrm{CD}^{+} \mathrm{T}$ cells derived from Stat $5^{f f f}$ or $\mathrm{Cd} 4-\mathrm{Cre}$; Stat $5^{\text {fff }}$ mice were transferred, followed by $\mathrm{MOG}_{35-55} / \mathrm{CFA}$ immunization as described above. Clinical symptoms were scored as follows: 0 , no clinical sign; 1 , loss of tail tone; 2 , wobbly gait; 3 , hind limb paralysis; 4, hind and fore limb paralysis; 5, death. IL-7R $\alpha$ neutralizing antibody (SB/14, BD Pharmingen) and isotype control was administrated intraperitoneally at $200 \mu \mathrm{g}$ per mouse every other day. For analysis of CNS-infiltrating cells, both spinal cord and brain were collected and minced from perfused mice, and mononuclear cells were isolated by gradient centrifuge with Percoll (GE Healthcare).

For passive EAE induction with Stat $^{+/+}$or Stat $^{-/-} \mathrm{CD}^{+} \mathrm{T}$ cells, splenocytes and LNs were harvested 10-14 days post-immunization and passed through a $70 \mu \mathrm{m}$ cell strainer (BD Falcon). Cells were cultured in vitro for 3 days with $\mathrm{MOG}_{35-55}(20 \mu \mathrm{g} / \mathrm{ml})$ in the presence of IL-23 (5 ng/ml) and IL-1 $\beta(2 \mathrm{ng} / \mathrm{ml})$. After harvesting, $\mathrm{CD}^{+} \mathrm{T}$ cells were purified by positive selection to a purity $>90 \%$. CD4 $4^{+} \mathrm{T}$ cells $\left(2 \times 10^{6}\right.$ in sterile PBS $)$ were injected intraperitoneally into $\mathrm{Rag} 2^{-/}$mice, followed by Pertussis toxin administration on the following day. Mice were observed daily for the signs of EAE as described above. For EAE induction by transferring various $\mathrm{T}_{\mathrm{H}}$ subsets, similar procedures were performed as described above. Different subsets skewing conditions were as follows: Non-skewed, $\mathrm{MOG}_{35-55}$ only; $\mathrm{T}_{\mathrm{H}} 1$ : $\mathrm{MOG}_{35-55}$ plus IL-12 $(10 \mathrm{ng} / \mathrm{ml})$ and anti-IL-4 $(5 \mu \mathrm{g} / \mathrm{ml}) ; \mathrm{T}_{\mathrm{H}} 17: \mathrm{MOG}_{35-55}$ plus TGF- $\beta$ (3 ng/ml), IL-6 (10 ng/ml), anti-IFN- $\gamma(5 \mu \mathrm{g} / \mathrm{ml})$ and anti-IL-4 (5 $\mu \mathrm{g} / \mathrm{ml})$; GM-CSF-producing $\mathrm{T}_{\mathrm{H}}: \mathrm{MOG}_{35-55}$ plus IL-7 (5ng/ml), and anti-IFN- $\gamma(5 \mu \mathrm{g} / \mathrm{ml}) .6 \times 10^{5} \mathrm{CD}^{+} \mathrm{T}$ cells were transferred per recipient mouse.

\section{T-cell transfer model of colitis}

$\mathrm{CD}^{+} \mathrm{T}$ cells were isolated from spleens and lymph nodes of WT, Cd4-Cre; Stat $3^{f f f}$ and Cd4-Cre; Stat $5^{f / f}$ mice by positive selection and magnetic separation (Miltenyi Biotech). Naïve CD4 $\mathrm{T}\left(\mathrm{CD} 4^{+} \mathrm{CD} 25^{-} \mathrm{CD} 45 \mathrm{RB}^{\mathrm{hi}}\right)$ cells were sorted with BD FACS Aria (purify $>98 \%$ ). $\operatorname{Rag}^{-/-}$mice were reconstituted with $4 \times 10^{5}$ naïve $\mathrm{CD}^{+} \mathrm{T}$ cells via intraperitoneal injection. Intestine inflammation was monitored up to 8 weeks. Cell suspensions were prepared from spleen, MLNs, and colon lamina propria by methods modified from previous report [52].

\section{Histological analysis}

For paraffin-embedded tissues, spinal cords, or colons were fixed in $4 \%$ PFA. Sections $(5 \mu \mathrm{m})$ were stained with hematoxylin and eosin (H\&E) to assess immune cell infiltration and inflammation. For frozen tissues, spinal cords were embedded in OCT (Tissue-Tek) and snap frozen on dry ice. Sections $(10 \mu \mathrm{m})$ were fixed in ice-cold acetone and stained with primary anti-CD4 (Biolegend) and anti-CD11b (eBioscience), followed by incubation with fluorescence-conjugated secondary antibodies (Invitrogen).

\section{Real-time PCR}

Total RNA was extracted from cells with RNeasy kit (Qiagen) according to the manufacturer's instruction. Complementary DNA 
(cDNA) was synthesized with Superscript reverse transcriptase (Invitrogen). Gene expressions were measured by 7500 real-time PCR system (Applied Biosystems) with SYBR qPCR kit (KAPA). Actinb, Gapdh, or Rn18S was used as internal control. The primer sequences are available upon request.

\section{Microarray assay}

For microarray analysis, RNA from naïve $\mathrm{T}$ cells, $\mathrm{T}_{\mathrm{H}} 1, \mathrm{~T}_{\mathrm{H}} 17$ and GM-CSF-producing $\mathrm{T}_{\mathrm{H}}$ cells was purified with RNeasy kit (Qiagen). Hybridization targets were amplified and labeled using Applause WT-Amp ST System according to the manufacturer's protocol (NuGEN). Labeled cDNA was hybridized to Affymetrix GeneChip Mouse Gene 1.0 ST according to the manufacturer's instructions. All microarray raw data (CEL files) were analyzed together using the Robust Multichip Average method to obtain the gene expression intensities. Normalization was then performed across all samples based on the cross correlation method [53]. Normalized data were further $\log 2$-tranformed and were used for identification of differentially expressed or $\mathrm{T}_{\mathrm{H}}$-cell specific genes. The cutoff fold change threshold of 1.5 was used for differential expression.

\section{ELISA}

GM-CSF level was assayed by Ready-SET-Go ELISA kit (eBioscience) according to the manufactures' instructions.

\section{Chromatin immunoprecipitation assays}

$\mathrm{CD}^{+}{ }^{+} \mathrm{T}$ cells isolated from Stat $5^{f / f}$ or Cd4-Cre; Stat $5^{f / f}$ mice were activated with plate-bound anti-CD3 and anti-CD28 for 3 days. Cells were stimulated with IL-7 (20 ng/ml) or IL-2 (25 ng/ $\mathrm{ml}$ ) for $45 \mathrm{~min}$. Crosslink was performed by addition of formaldehyde at final concentration of $1 \%$ for 10 min followed by quenching with glycine. Cell lysates were fragmented by sonication and precleared with protein G Dynabeads, and subsequently precipitated with anti-STAT5 antibody (Santa Cruz) or normal rabbit IgG (Santa Cruz) overnight at $4{ }^{\circ} \mathrm{C}$. After washing and elution, crosslink reversal was done by incubating at $65^{\circ} \mathrm{C}$ for $8 \mathrm{~h}$. The eluted DNA was purified and analyzed by RT-PCR with primers specific to $C s f 2$ promoter as described previously [54].

\section{Statistics}

Statistical significance was determined by Student's $t$-test using GraphPad Prism 6.01. $P<0.05$ was considered significant. The $P$ values of clinical scores were determined by one-way multiple-range analysis of variance (ANOVA) for multiple comparisons. Unless otherwise specified, data were presented as mean \pm SEM.

\section{Acknowledgments}

We thank Lothar Hennighausen and Arian Laurence (NIH, USA) for providing Stat5-floxed mice and expert advice on working with $\mathrm{T}_{\mathrm{H}} 17$ cells, respectively; Chen Dong (MD Anderson) and Jianzhu Chen (MIT) for comments and suggestions on the manuscript; Jean-Pierre Abastado (Singapore Immunology Network) and Veronique Angeli (NUS) for help with mouse strains. Sheng W was supported by a scholarship from the Department of Biological Sciences, National University of Singapore. Work at Indiana University and Moh A were supported by Public Health Service
(CA125568 to XYF and AI045515 to MHK). This work is supported by grants from the Singapore National Medical Research Council (NMRC/1233/2009 toXYF and IRG10nov091 to YZ), from the Ministry of Education (MOE2010-T2-084 to XYF and MOE2010-T2-079 to YZ), funds from the Office of Deputy President (DPRT) of National University of Singapore (to XYF and YZ), and funds from the NUHS Memory, Ageing and Cognition Centre (MACC), SICS-09/1/1/002 and CSI (to XYF).

\section{References}

1 O'Shea JJ, Paul WE. Mechanisms underlying lineage commitment and plasticity of helper CD4+ T cells. Science 2010; 327:1098-1102.

2 Littman DR, Rudensky AY. Th17 and regulatory T cells in mediating and restraining inflammation. Cell 2010; 140:845858.

3 Dong C. TH17 cells in development: an updated view of their molecular identity and genetic programming. Nat Rev Immunol 2008; 8:337-348.

4 Kaplan MH, Sun YL, Hoey T, Grusby MJ. Impaired IL-12 responses and enhanced development of Th2 cells in Stat4-deficient mice. Nature 1996; 382:174-177.

5 Thierfelder WE, van Deursen JM, Yamamoto K, et al. Requirement for Stat4 in interleukin-12-mediated responses of natural killer and T cells. Nature 1996; 382:171-174.

6 Szabo SJ, Kim ST, Costa GL, Zhang X, Fathman CG, Glimcher LH. A novel transcription factor, T-bet, directs Th1 lineage commitment. Cell 2000; 100:655-669.

7 Bettelli E, Carrier Y, Gao W, et al. Reciprocal developmental pathways for the generation of pathogenic effector TH17 and regulatory T cells. Nature 2006; 441:235-238.

8 Harris TJ, Grosso JF, Yen HR, et al. Cutting edge: an in vivo requirement for STAT3 signaling in TH17 development and TH17-dependent autoimmunity. J Immunol 2007; 179:43134317.

9 Yang XO, Panopoulos AD, Nurieva R, et al. STAT3 regulates cytokine-mediated generation of inflammatory helper T cells. J Biol Chem 2007; 282:9358-9363.

10 Veldhoen M, Hocking RJ, Atkins CJ, Locksley RM, Stockinger B. TGFbeta in the context of an inflammatory cytokine milieu supports de novo differentiation of IL-17-producing T cells. Immunity 2006; 24:179-189.

11 Zhu J, Paul WE. CD4 T cells: fates, functions, and faults. Blood 2008; 112:1557-1569.

12 Becher B, Segal BM. T(H)17 cytokines in autoimmune neuro-inflammation. Curr Opin Immunol 2011; 23:707-712.

13 Goverman J. Autoimmune T cell responses in the central nervous system. Nat Rev Immunol 2009; 9:393-407.

14 Becher B, Durell BG, Noelle RJ. Experimental autoimmune encephalitis and inflammation in the absence of interleukin-12. J Clin Invest 2002; 110:493-497.

15 Chu CQ, Wittmer S, Dalton DK. Failure to suppress the expansion of the activated CD4 $\mathrm{T}$ cell population in interferon gamma-deficient mice leads to exacerbation of experimental autoimmune encephalomyelitis. J Exp Med 2000; 192:123128.

16 Cua DJ, Sherlock J, Chen Y, et al. Interleukin-23 rather than interleukin-12 is the critical cytokine for autoimmune inflam- 
mation of the brain. Nature 2003; 421:744-748.

17 Gran B, Zhang GX, Yu S, et al. IL-12p35-deficient mice are susceptible to experimental autoimmune encephalomyelitis: evidence for redundancy in the IL-12 system in the induction of central nervous system autoimmune demyelination. $J$ Immunol 2002; 169:7104-7110.

18 Ivanov II, McKenzie BS, Zhou L, et al. The orphan nuclear receptor RORgammat directs the differentiation program of proinflammatory IL-17+ T helper cells. Cell 2006; 126:11211133.

19 Haak S, Croxford AL, Kreymborg K, et al. IL-17A and IL$17 \mathrm{~F}$ do not contribute vitally to autoimmune neuro-inflammation in mice. $J$ Clin Invest 2009; 119:61-69.

20 Kreymborg K, Etzensperger R, Dumoutier L, et al. IL-22 is expressed by Th17 cells in an IL-23-dependent fashion, but not required for the development of autoimmune encephalomyelitis. J Immunol 2007; 179:8098-8104.

21 Codarri L, Gyulveszi G, Tosevski V, et al. RORgammat drives production of the cytokine GM-CSF in helper T cells, which is essential for the effector phase of autoimmune neuroinflammation. Nat Immunol 2011; 12:560-567.

22 El-Behi M, Ciric B, Dai H, et al. The encephalitogenicity of $\mathrm{T}(\mathrm{H}) 17$ cells is dependent on IL-1- and IL-23-induced production of the cytokine GM-CSF. Nat Immunol 2011; 12:568575.

23 Ponomarev ED, Shriver LP, Maresz K, Pedras-Vasconcelos J, Verthelyi D, Dittel BN. GM-CSF production by autoreactive $\mathrm{T}$ cells is required for the activation of microglial cells and the onset of experimental autoimmune encephalomyelitis. $J$ Immunol 2007; 178:39-48.

24 Yao Z, Kanno Y, Kerenyi M, et al. Nonredundant roles for Stat5a/b in directly regulating Foxp3. Blood 2007; 109:43684375.

25 Laurence A, Tato CM, Davidson TS, et al. Interleukin-2 signaling via STAT5 constrains T helper 17 cell generation. Immunity 2007; 26:371-381.

26 Yang XP, Ghoreschi K, Steward-Tharp SM, et al. Opposing regulation of the locus encoding IL-17 through direct, reciprocal actions of STAT3 and STAT5. Nat Immunol 2011; 12:247254.

27 Cui Y, Riedlinger G, Miyoshi K, et al. Inactivation of Stat5 in mouse mammary epithelium during pregnancy reveals distinct functions in cell proliferation, survival, and differentiation. Mol Cell Biol 2004; 24:8037-8047.

28 Burchill MA, Yang J, Vogtenhuber C, Blazar BR, Farrar MA. IL-2 receptor beta-dependent STAT5 activation is required for the development of Foxp3+ regulatory T cells. J Immunol 2007; 178:280-290.

29 Reboldi A, Coisne C, Baumjohann D, et al. C-C chemokine receptor 6-regulated entry of TH-17 cells into the CNS through the choroid plexus is required for the initiation of EAE. Nat Immunol 2009; 10:514-523.

30 Sporici R, Issekutz TB. CXCR3 blockade inhibits T-cell migration into the CNS during EAE and prevents development of adoptively transferred, but not actively induced, disease. Eur J Immunol 2010; 40:2751-2761.

31 Lee LF, Logronio K, Tu GH, et al. Anti-IL-7 receptor-alpha reverses established type 1 diabetes in nonobese diabetic mice by modulating effector T-cell function. Proc Natl Acad Sci
USA 2012; 109:12674-12679.

32 Mirabella F, Baxter EW, Boissinot M, James SR, Cockerill PN. The human IL-3/granulocyte-macrophage colony-stimulating factor locus is epigenetically silent in immature thymocytes and is progressively activated during T cell development. J Immunol 2010; 184:3043-3054.

33 Durant L, Watford WT, Ramos HL, et al. Diverse targets of the transcription factor STAT3 contribute to T cell pathogenicity and homeostasis. Immunity 2010; 32:605-615.

34 Zhu J, Yamane H, Paul WE. Differentiation of effector CD4 T cell populations (*). Annu Rev Immunol 2010; 28:445-489.

35 Noster R, Riedel R, Mashreghi MF, et al. IL-17 and GM-CSF expression are antagonistically regulated by human $\mathrm{T}$ helper cells. Sci Transl Med 2014; 6:241ra280.

36 Chavany C, Vicario-Abejon C, Miller G, Jendoubi M. Transgenic mice for interleukin 3 develop motor neuron degeneration associated with autoimmune reaction against spinal cord motor neurons. Proc Natl Acad Sci USA 1998; 95:1135411359.

37 Yamada R, Tanaka T, Unoki M, et al. Association between a single-nucleotide polymorphism in the promoter of the human interleukin-3 gene and rheumatoid arthritis in Japanese patients, and maximum-likelihood estimation of combinatorial effect that two genetic loci have on susceptibility to the disease. Am J Hum Genet 2001; 68:674-685.

38 Bruhl H, Cihak J, Niedermeier M, et al. Important role of interleukin-3 in the early phase of collagen-induced arthritis. Arthritis Rheum 2009; 60:1352-1361.

39 Chu X, Dong C, Lei R, et al. Polymorphisms in the interleukin 3 gene show strong association with susceptibility to Graves' disease in Chinese population. Genes Immun 2009; 10:260-266.

40 Malek TR. The biology of interleukin-2. Annu Rev Immunol 2008; 26:453-479.

41 Rochman Y, Spolski R, Leonard WJ. New insights into the regulation of T cells by gamma(C) family cytokines. Nat Rev Immunol 2009; 9:480-490.

42 Aiello FB, Keller JR, Klarmann KD, Dranoff G, Mazzucchelli $\mathrm{R}$, Durum SK. IL-7 induces myelopoiesis and erythropoiesis. J Immunol 2007; 178:1553-1563.

43 Gregory SG, Schmidt S, Seth $\mathrm{P}$, et al. Interleukin 7 receptor alpha chain (IL7R) shows allelic and functional association with multiple sclerosis. Nat Genet 2007; 39:1083-1091.

44 Lundmark F, Duvefelt K, Iacobaeus E, et al. Variation in interleukin 7 receptor alpha chain (IL7R) influences risk of multiple sclerosis. Nat Genet 2007; 39:1108-1113.

45 Lee LF, Axtell R, Tu GH, et al. IL-7 promotes T(H)1 development and serum IL-7 predicts clinical response to interferon-beta in multiple sclerosis. Sci Transl Med 2011; 3:93ra68.

46 McGeachy MJ, Chen Y, Tato CM, et al. The interleukin 23 receptor is essential for the terminal differentiation of interleukin 17-producing effector T helper cells in vivo. Nat Immunol 2009; 10:314-324.

47 Croxford AL, Mair F, Becher B. IL-23: one cytokine in control of autoimmunity. Eur J Immunol 2012; 42:2263-2273.

48 Kaser A, Zeissig S, Blumberg RS. Inflammatory bowel disease. Annu Rev Immunol 2010; 28:573-621.

49 Fukuzawa H, Sawada M, Kayahara T, et al. Identification of GM-CSF in Paneth cells using single-cell RT-PCR. Biochem 
Biophys Res Commun 2003; 312:897-902.

50 Welte T, Zhang SS, Wang T, et al. STAT3 deletion during hematopoiesis causes Crohn's disease-like pathogenesis and lethality: a critical role of STAT3 in innate immunity. Proc Natl Acad Sci USA 2003; 100:1879-1884.

51 Zhang Y, Reynolds JM, Chang SH, et al. MKP-1 is necessary for T cell activation and function. J Biol Chem 2009; 284:30815-30824.

52 Uhlig HH, McKenzie BS, Hue S, et al. Differential activity of IL-12 and IL-23 in mucosal and systemic innate immune pathology. Immunity 2006; 25:309-318.

53 Chua SW, Vijayakumar P, Nissom PM, Yam CY, Wong VV, Yang H. A novel normalization method for effective removal of systematic variation in microarray data. Nucleic Acids Res
2006; 34:e38.

54 Chen X, Wang J, Woltring D, Gerondakis S, Shannon MF. Histone dynamics on the interleukin-2 gene in response to T-cell activation. Mol Cell Biol 2005; 25:3209-3219.

(Supplementary information is linked to the online version of the paper on the Cell Research website.)

(c) (i) () $(-)$ This work is licensed under the Creative Commons Attribution-NonCommercial-No Derivative Works 3.0 Unported License. To view a copy of this license, visit http:// creativecommons.org/licenses/by-nc-nd/3.0 